DOI: 10.32089/WBH.PHW.2021.2(276).0008

orcid.org/0000-0001-9174-2939

\author{
KAROL SACEWICZ
}

Uniwersytet Warmińsko-Mazurski, Delegatura Instytutu Pamięci Narodowej w Olsztynie

\title{
Sytuacja militarina uczestnilków wojny wietnamskiej w świetle fragmentów materiału lektorskiego Wydziału Propagandy i Agitacji KC PZPR pt. Uwagi o dynamice konfliktu wietnamskiego (czerwiec 1966)
}

\begin{abstract}
This text is a critical edition of a fragment of a document concerning the military aspects of the Vietnam War that was taking place at that time. It is not only an attempt to present a Polish People's propaganda way of seeing the Vietnam War, but it also reveals the existence of communist manipulation and the process behind the creation of an ahistorical image of the Vietnamese struggle.

Od marca 1965 r., kiedy na plażach niedaleko Da Nang wylądowały pierwsze regularne jednostki wojsk amerykańskich, ${ }^{1}$ rozpoczęła się „oficjalna" interwencja zbrojna Stanów Zjednoczonych w Wietnamie Południowym. Waszyngton już od lat pięćdziesiątych był zaangażowany na Półwyspie Indochińskim, finansowo i politycznie wspierając Francuzów w ich walce z Vieth Minhem, podczas tzw. I wojny indochińskiej, a następnie po

Zob. Karol Sacewicz, „Zanim była Ofensywa Tet. Sytuacja operacyjna wojsk amerykańskich i sojuszniczych w Wietnamie Południowym w 1967 r. i jej wpływ na walki w dolinie Dak To w świetle materiałów Zarządu II Sztabu Generalnego Wojska Polskiego. Krytyka źródła," Pamięć i Sprawiedliwość, nr 35 (2019): 366; Gabriel Kolko, Anatomy of a War. Vietnam, the United States and the Modern Historical Experience (New York: Pantheon, 1986), 165.
\end{abstract}


układach genewskich, w sposób bezpośredni kreując sytuację polityczno-militarną w Azji Południowo-Wschodniej. ${ }^{2}$ Wyrazem tej polityki Białego Domu, która w swoim założeniu miała powstrzymywać rozwój komunizmu w tym rejonie świata i chronić go przed czarnym scenariuszem bezczynności zawartym w haśle „teoria domina”, było wspieranie rządów Ngo Dinh Diema. ${ }^{3}$ To oznaczało m.in. udzielenie militarnej pomocy siłom południowowietnamskim w pierwszych latach ich walki przeciwko komunistycznej partyzantce (Viet Cong - VC), jak również przeciwko skutkom infiltracji granicy przez siły zbrojne Demokratycznej Republiki Wietnamu (DRW).

Wojna ta $\mathrm{z}$ każdym rokiem coraz mocniej skupiała całą gamę reakcji i interakcji we wzajemnych stosunkach politycznych pomiędzy państwami dwóch ówcześnie dominujących bloków polityczno-militarnych. Szczególnie odczuwalne było to od przełomu 1963 r. i 1964 r. Wówczas nad Potomakiem ostatecznie zarzucono ewentualność ograniczenia pomocy dla władz sajgońskich. To, przy jednoczesnym, coraz bardziej agresywnym, nacisku bojowym sił komunistycznych wspieranych przez Moskwę, jej satelitów oraz Pekin, których ofiarami stawali się doradcy amerykańscy w Wietnamie Południowym, doprowadziło waszyngtońskich decydentów do opowiedzenia się za bardziej zdecydowanym niż dotychczas, opartym na regularnych jednostkach wojskowych, zaangażowaniu się USA w Indochinach. W sposób naturalny wydarzenia te stawały się elementem wielkiej polityki doby „zimnej wojny”.

Niemniej jednak błędem byłoby ograniczać oddziaływanie wojny wietnamskiej tylko do najwyższego poziomu decyzyjnego w Moskwie i Waszyngtonie. $\mathrm{Z}$ racji zimnowojennej konfrontacji, która nie rozgrywała się wyłącznie na płaszczyźnie militarnej, ale dotyczyła całego spektrum relacji między Wschodem i Zachodem, problematyka wietnamska determinowała w znaczący sposób inne sektory zewnętrznej oraz wewnętrznej działalności państw trzecich oficjalnie niezaangażowanych w rzeczoną wojnę, czego przykładem jest rządzona przez komunistów Polska. Jako członek Układu Warszawskiego i satelita ZSRS zobligowana była do wspierania Hanoi w jego wojnie z Sajgonem, co też czyniła. Jednym z elementów polityki ideowej solidarności z DRW była akcja propagandowa prowadzona przez polską dyplomację na płaszczyźnie międzynarodowej, jak i wewnątrzkrajowa wykonywana przede wszystkim przez struktury partyjne. Te ostatnie,

\footnotetext{
2 Zob. Piotr Ostaszewski, Wietnam. Najdłuższy konflikt powojennego świata 1945-1975 (Warszawa: „DiG”, 2000), 263 i n.

3 Ngo Dinh Diem (ur. 1901 - zm. 1963) - wietnamski polityk, od 1955 r. prezydent Republiki Wietnamu, katolik, zamordowany podczas zamachu wojskowego 2 XI 1963 r. Należy tu podkreślić, że często - nawet w literaturze naukowej - błędnie imię Diem było traktowane jako jego nazwisko.
} 
pomimo rzeczywistej peryferyjności wojny wietnamskiej, traktowały ją jako aktualny i niezmiernie istotny obszar walk $\mathrm{z}$ „amerykańskim imperializmem", tworząc nowy, własny, propagandowy front krwawego konfliktu rozgrywającego się w Azji Południowo-Wschodniej - tysiące kilometrów od Wisły.

Oczywiście z amerykańskiego punktu widzenia wspomniane akcje propagandowe nie stanowiły dużego zagrożenia, bowiem skala oddziaływania propagandy PRL była ograniczona de facto do własnego społeczeństwa i co najwyżej do państw tzw. bloku socjalistycznego. Jej celem była chęć „właściwego" naświetlania problematyki wojennej i kreowanie wizerunku złych i agresywnych ,amerykańskich imperialistów”, przy jednoczesnym kształtowaniu obrazu komunistów z VC i DRW jako niewinnych oraz sprawiedliwych obrońców pokoju i „socjalizmu” na świecie. Istotnym instrumentem akcji propagandowej była oczywiście prasa, w ogóle szeroko rozumiana publicystyka, ${ }^{4}$ niemniej jednak na poziomie kreowania opinii o wojnie, wyznaczania kierunków jej postrzegania i opisywania rudymentarną rolę odgrywały wytyczne Komitetu Centralnego Polskiej Zjednoczonej Partii Robotniczej (KC PZPR), które zawarte zostały m.in. w przygotowywanych przez Wydział Propagandy i Agitacji KC PZPR materiałach lektorskich. Wysyłano je według przyjętego rozdzielnika do komitetów wojewódzkich (KW) partii z nakazem ich rozpowszechniania przez lektorów podczas tematycznych spotkań podstawowych organizacji partyjnych w zakładach pracy oraz podczas kontaktów z lokalnymi mediami. 29 czerwca $1966 \mathrm{r}$. Wydział Propagandy i Agitacji KC PZPR rozesłał do komitetów wojewódzkich materiał lektorski pt. Uwagi o dynamice konfliktu wietnamskiego. ${ }^{5} \mathrm{~W}$ sumie przygotowano 1850 egz. wykładu. Najwięcej, bo po 140 szt., trafiło do KW PZPR w Katowicach, Poznaniu i we Wrocławiu, 130 na teren województwa warszawskiego, po 100 egz. do KW PZPR w Bydgoszczy, Rzeszowie oraz w Krakowie, po 80 egz. do KW w Gdańsku, Lublinie, Łodzi, Opolu, Zielonej Górze plus do komitetu miejskiego partii w Warszawie i na teren województwa łódzkiego. Ponadto do KW PZPR w Koszalinie, Olsztynie i w Szczecinie wysłano po 60 egz., 10 szt. opracowania lektorskiego pochodzących z rezerw Wydziału Propagandy i Agitacji KC przekazano do Głównego Zarządu Politycznego Wojska Polskiego, po 5 do Związku

\footnotetext{
4 Zob. Ewa Maj, „Zaangażowanie Stanów Zjednoczonych w konflikt wietnamski w świetle polskiej propagandy prasowej (1964-1968)," w Zimowa Szkoła Historii Najnowszej 2014. Referaty, red. Marek Hańderek i Łukasz Kamiński (Warszawa: Wyd. Instytutu Pamięci Narodowej, 2015), 108-118.

5 Zob. Archiwum Akt Nowych (dalej: AAN), Komitet Centralny Polskiej Zjednoczonej Partii Robotniczej Wydział Propagandy i Agitacji (dalej: KC PZPR Wydział Propagandy i Agitacji), 1354/237/VIII-827, „Uwagi o dynamice konfliktu wietnamskiego /Materiał lektorski/", Warszawa, czerwiec 1966 r., 23-41v.
} 
Młodzieży Socjalistycznej i Związku Młodzieży Wiejskiej oraz 1 egzemplarz do Komendy Głównej Ochotniczych Hufców Pracy. ${ }^{6}$

Materiał lektorski odzwierciedlał nie tylko komunistyczną wizję wojny, ale także stan wiedzy o tym konflikcie, jakim dysponowały oficjalne władze partyjne w Polsce. Oczywiście należy mieć przy tym pełną świadomość, że przede wszystkim był on instrumentem komunistycznej ofensywy propagandowej ukierunkowanej na indoktrynację społeczeństwa. Analiza treści wykładu, nawet tylko fragmentu odnoszącego się do militarnych aspektów wojny wietnamskiej, odkrywa obszary, w których nastąpiła „inteligentna” manipulacja danymi, faktami, a także to, w jaki sposób ukierunkowana została jego narracja, aby odbiór tylko jednej ze stron konfliktu był negatywny. ${ }^{7}$ Prezentowany fragment dokumentu jest spojrzeniem propagandy PZPR na kwestie narodzin i rozwoju tzw. II konfliktu indochińskiego, od momentu wycofania się z Półwyspu Francuzów i zastąpienia ich przez siły amerykańskie. Jego cechą charakterystyczną jest dominacja przykładów nieskutecznego prowadzenia wojny przez USA, braku doktrynalnych uwarunkowań nakazujących i uzasadniających amerykańską obecność polityczno-militarną w Azji Południowo-Wschodniej, przy jednoczesnej akceptacji wszelkiej aktywności sił komunistycznych w Wietnamie Południowym. Wykład dokonuje de facto podziału stron konfliktu na sprawiedliwą oraz złą. Oczywiście za tę pierwszą są uważani komuniści z VC, jak i cała DRW, drugą stanowi tzw. reżim sajgoński oraz jego protektor - Stany Zjednoczone. Dla potwierdzenia słuszności swojego wywodu autor(zy) wykładu lektorskiego - nie ma bowiem możliwości wskazania jednej, konkretnej osoby, która stworzyła rzeczony materiał - nie tylko przywoływał dane statystyczne o stratach, jakie ponoszą siły amerykańskie, zawyżając je, o kosztach finansowych wojny, ale także o braku jakichkolwiek militarnych postępów oraz sukcesów w dotychczasowych zmaganiach, co było dalekie od prawdy. Nie podawano przy tym żadnych informacji o stratach sił komunistycznych. Co prawda wykład opierał się na treściach zaczerpniętych $\mathrm{z}$ amerykańskiej prasy polityczno-informacyjnej, jednak warty podkreślenia, i nie bez znaczenia dla jego treści, jest fakt, że korzystano głównie z tytułów prasowych negatywnie ustosunkowanych wobec amerykańskiego zaangażowania w Azji Południowo-Wschodniej, a także z tekstów lub wypowiedzi publicystów i polityków nieprzychylnych wojnie wietnamskiej, jak i samej administracji prezydenta Lyndona B. Johnsona. Tym samym przeplatanie fragmentów tekstów - znamienitych skądinąd publicystów

6 Ibid., Rozdzielnik na materiał lektorski pt. „Uwagi o dynamice konfliktu wietnamskiego”, Warszawa, 29 VI 1966 r., 22.

7 Zob. m.in. przypisy nr 70 i 73. 
jak James Reston ${ }^{8}$ czy Richard Dudman ${ }^{9}$ - ze stanowiskami amerykańskich kongresmanów otwarcie występujących przeciw obecności armii Stanów Zjednoczonych w Wietnamie, tj. Johna Fulbrighta ${ }^{10}$ i Michaela Mansfiel$\mathrm{da}^{11}$, przy jednoczesnym braku jakiejkolwiek obiektywnej opinii analizującej zasadność decyzji Białego Domu o wejściu do indochińskiego konfliktu, wytwarza dość jednoznaczny, niekorzystny dla Waszyngtonu obraz. Nie może on dziwić, bo mamy tutaj do czynienia $\mathrm{z}$ materiałem wykonanym przez partyjną komórkę propagandowo-agitacyjną, którego przeznaczenie było dość jednoznaczne i nie miało nic wspólnego z naukowym odzwierciedleniem militarnej rzeczywistości ze wszystkimi jej odcieniami. Cóż więc otrzymaliśmy? Odpowiedź jest dość oczywista - tekst, który jest bardzo sprawnym instrumentem propagandowym, a przede wszystkim bardzo dobrym przykładem inteligentnej manipulacji.

Omawiany materiał lektorski składa się z kilku części poświęconych następującym zagadnieniom: 1) przebiegowi działań zbrojnych w Wietnamie, 2) ocenie i „analizie” realiów politycznej sceny wietnamskiej, 3) postrzeganiu konfliktu w świecie zachodnim, 4) reakcji społeczeństwa amerykańskiego, 5) reperkusji w łonie obozu socjalistycznego, 6) potencjalnym warunkom uregulowania konfliktu. Niniejszy tekst został ograniczony do edycji źródłowej pierwszej części materiału lektorskiego, tj. przedstawienia zagadnienia sytuacji wojskowej w Wietnamie. To właśnie kwestie zbrojnej aktywności USA na Półwyspie Indochińskim były w wymiarze propagandowym najbardziej rozpoznawalnym elementem całej wojny, a wobec przedłużającego się konfliktu, rosnących strat i oddalającej się szansy na zwycięskie zakończenie zmagań stawały się bardzo łatwym celem propagandowych ataków ze strony komunistycznej. Nie bez wpływu na analizowanie jedynie fragmentu materiału lektorskiego pozostawał fakt, iż rzeczony materiał jest obszerny i ze względów redakcyjnych nie mógł się ukazać w całości, ponadto ujęcie jedynie „militarnej” części wykładu było reprezentatywne dla całego zagadnienia - wojny w Wietnamie, a przez to dla poznania mechanizmów i form komunistycznej propagandy.

8 James B. Reston (ur. 1909 - zm. 1995) - urodzony w Szkocji amerykański dziennikarz, podczas II wojny światowej pracował w US Office of War Information w Londynie, później m.in. w redakcji The Times oraz The New York Times.

9 Richard Dudman (ur. 1918 - zm. 2017) - amerykański dziennikarz, relacjonował wydarzenia na Kubie, informował o zabójstwie prezydenta Kennedy’ego, a także o konflikcie w Wietnamie oraz w Kambodży.

10 J. William Fulbright, właśc. John William Fulbright (ur. 1905 - zm. 1995) - prawnik, polityk, z ramienia Partii Demokratycznej członek Izby Reprezentantów oraz Senatu, wieloletni przewodniczący senackiej komisji spraw zagranicznych.

11 Michael J. Mansfield (ur. 1903 - zm. 2001) - amerykański polityk, od 1952 r. senator, lider Partii Demokratycznej, przeciwnik zaangażowania się USA na Półwyspie Indochińskim. 
Tekst został opracowany zgodnie z instrukcją wydawniczą. Ortografia i interpunkcja zostały uwspółcześnione.

\section{UWAGI O DYNAMICE KONFLIKTU WIETNAMSKIEGO /materiał lektorski/}

\section{Warszawa, czerwiec, 1966}

Truizmem jest stwierdzenie, że wojna w Wietnamie zogniskowała centralną problematykę współczesnych stosunków międzynarodowych. Ale logicznym wnioskiem tej konstatacji jest uznanie określonego związku między kierunkiem rozwoju głównych wydarzeń w świecie z rozwojem konfliktu wietnamskiego. $\mathrm{W}$ istocie zazębienie to występuje wyraźnie w przegrupowaniach i przesunięciach na arenie międzynarodowej lat ostatnich. Sprawa wietnamska i eskalacji wojny w Indochinach stała się katalizatorem wielu węzłowych procesów politycznych. Wokół osi wietnamskiej obracają się i krystalizują nowe układy w różnych przekrojach stosunków międzynarodowych: między Wschodem i Zachodem, w łonie świata zachodniego, w międzynarodowym ruchu robotniczym i między państwami socjalistycznymi. Konflikt w Wietnamie wywiera decydujący wpływ na kształtowanie się naczelnej problematyki naszych czasów - sprawy wojny i pokoju.

Problemem o znaczeniu kapitalnym jest przesunięcie punktu ciężkości polityki i strategii Stanów Zjednoczonych ze sceny europejskiej do Azji. ${ }^{12}$ Mimo iż proces ten nie osiągnął jeszcze swego rozwoju szczytowego, jego konsekwencje zarysowały się już z dużą ostrością. Trudno $\mathrm{w}$ istocie przecenić wagę tego zwrotu, zwłaszcza $w$ reperkusjach na arenie europejskiej. Jeszcze poważniejsze wszakże wydają się konsekwencje zachodzących przemian

12 Należy zauważyć, że wobec ówczesnej eskalacji militarnych napięć w Azji takie działania Waszyngtonu były ze wszech miar uzasadnione. Od kryzysu berlińskiego w 1948 r., krwawych wydarzeń w NRD w 1953 r. i rewolucji węgierskiej w 1956 r. Europa na tle Azji wydawała się obszarem wyjątkowo stabilnym, mimo trwania zimnej wojny. Po zwycięstwie komunistów w Chinach w 1949 r., klęsce Francuzów w Indochinach, de facto nierozstrzygniętej wojnie koreańskiej, fali komunistycznych rebelii m.in. w Malezji oraz na Filipinach zaangażowanie USA w powstrzymywanie ekspansji polityczno-militarnej komunizmu było, z punktu widzenia Zachodu, działaniem naturalnym (oczywiście nie oznacza to pozytywnej oceny doboru form, środków i celu takich działań). Zwłaszcza że już w lutym 1950 r. w Memorandum Narodowej Rady Bezpieczeństwa nie tylko stwierdzano kluczową rolę Azji Południowo-Wschodniej w amerykańskim systemie bezpieczeństwa, ale nakazywano podjąć wszelkie możliwe środki, aby powstrzymać dalszą ekspansję komunizmu w tym rejonie świata; „Document 1, Report by the National Security Council on the Position of the United States with Respect to Indochina, 27 February 1950," w The Pentagon Papers. Gravel Edition, red. Mike Gravel, t. 1-4 (Boston: Beacon Pess, 1972), 1:361-362, https://www.mtholyoke. edu/acad/intrel/pentagon/doc1.htm, dostęp luty 21, 2020; John Pimlott, Wojna w Wietnamie, tłum. Małgorzata Malczyk (Warszawa: „Morex”, 1993), 27. 
w nowym rozłożeniu akcentów amerykańskiej doktryny politycznej i myśli wojskowej. Cechą dominującą nowych prądów wiejących z Pentagonu i Departamentu Stanu jest ostry wzrost tendencji agresywnych - tego co senator Fulbright nazwał „arrogance of power” ${ }^{13}$, a co w praktyce jest wyniesieniem polityki z pozycji siły do roli wiodącej $\mathrm{w}$ amerykańskiej polityce zagranicznej.

$\mathrm{U}$ podstaw tego rozwoju legły głębokie zmiany strukturalne $\mathrm{w}$ gospodarce, społeczeństwie i aparacie władzy Stanów Zjednoczonych. Rewolucja przemysłowa związana $\mathrm{z}$ burzliwym rozwojem elektroniki niepomiernie umocniła wpływy wielkiego przemysłu, kapitału finansowego i wojska na kierunku amerykańskiej polityki zagranicznej. Symbolem przesunięć na szczeblu planowania i realizacji tej polityki stała się działalność Centralnej Agencji Wywiadowczej C.I.A. ${ }^{14}$ Coraz mężniej występuje zjawisko przerostu wiary w nieograniczoną potęgę ekonomiczną, techniczną i wojskową Stanów Zjednoczonych. Wraz z przebudzeniem aspiracji globalnych nastąpiło ogólne spłycenie myśli politycznej. O kierunkach działania coraz częściej decydują bardziej sztywne schematy maszyn automatycznych niż żywe realia stosunków międzyludzkich w świecie. Zanik realizmu i trzeźwości sądu w decydujących kręgach administracji amerykańskiej zrodził wyjątkowe zagrożenie dla mocno zachwianej konfliktem wietnamskim równowagi politycznej na arenie międzynarodowej. ${ }^{15}$

Niezwykle złożona problematyka staje przed światem socjalistycznym. Wyrwę zrodzoną przez rozbieżności ideologiczne i polityczne imperializm amerykański usiłuje wypełnić i pogłębić przez zastosowanie selektywnego współistnienia i wyizolowania wojny wietnamskiej ze sfery współdziałania państw socjalistycznych. Celowi temu ma służyć m.in. teoria wojen

13 J. William Fulbright, The Arrogance of Power (New York: Random House Publishing Group, 1967).

14 Szerzej na temat działalności CIA i oceny przez nią sytuacji w Wietnamie zob. Estimative Products on Vietnam 1948-1975, red. John K. Allen Jr., John Carver i Tom Elmore (Pittsburgh: Government Printing Office, 2005); Thomas L. Ahern. Jr., CIA and the Generals Covert Support to Military Government in South Vietnam (b.m.w.: Center for the Study of Intelligence, [1998]), passim; Athern, CIA and Rural Pacification in South Vietnam (b.m.w.: Center for the Study of Intelligence, [2001]), passim.

15 Lansowana przez komunistyczną propagandę teza o rzekomym braku koncepcji strategicznych uzasadniających działania USA w Azji Południowo-Wschodniej nie znajduje potwierdzenia w faktach. Administracja waszyngtońska, począwszy od prezydentury Harry'ego Trumana, poprzez dwie kadencje Dwighta Eisenhowera i trzy lata rządów Johna Kennedy'ego, angażując się w konflikt indochiński, czyniła to w oparciu o wypracowane doktryny określające i warunkujące cele, wyznaczające linie bezpieczeństwa zewnętrznego Stanów Zjednoczonych, działała w imię i w zgodzie z amerykańską racją stanu. Zob. Marcin Adamczyk i Oskar Szuflet, Indochiny w amerykańskiej polityce powstrzymywania do 1963 roku (Poznań: Wyd. Wierzejewski, 2017), passim. 
lokalnych ${ }^{16}$ będąca $\mathrm{w}$ istocie zaprzeczeniem prawdy o niepodzielności pokoju. ${ }^{17}$ Zagadnienia te stawiają $\mathrm{w}$ nowym świetle i zmuszają do przemyślenia szeregu problemów taktyki i strategii świata socjalistycznego. Rzutują szczególnie żywo na sprawy frontu ideologicznego.

Wszystko to skłania do bacznej obserwacji sceny wietnamskiej i nieustannej analizy związanych $\mathrm{z}$ wojną $\mathrm{w}$ Wietnamie wydarzeń. Problemem doniosłym jest zwłaszcza właściwe odczytanie kierunków rozwojowych tej wojny.

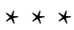

Próba określenia dynamiki rozwojowej wojny w Wietnamie wymaga zwrócenia uwagi na następujące elementy sytuacji:

- przebieg działań zbrojnych w Wietnamie,

- realia polityczne sceny wietnamskiej,

- odbicie konfliktu w świecie zachodnim,

- reakcja społeczeństwa amerykańskiego,

- reperkusje w łonie obozu socjalistycznego,

- potencjalne warunki uregulowania konfliktu.

16 Na temat pojęcia wojen lokalnych i ich charakterystyki w dobie konfliktów zimnowojennych szerzej zob. Juliusz S. Tym, „Konflikty lokalne podczas zimnej wojny jako wyraz konfrontacji zbrojnej mocarstw bez wypowiedzenia wojny," Studia Martima 29, (2016): 236-238, 242-246.

17 Mowa o liberalnym nurcie postrzegania relacji międzynarodowych, którego jedną z cech charakterystycznych jest założenie o niepodzielności pokoju oraz o współzależności uczestników stosunków międzynarodowych. Należy jednak pamiętać, że samo pojęcie pokoju było wówczas de facto niedookreślone. Co prawda popularne były studia nad pokojem, zastępujące - zwłaszcza w krajach skandynawskich - badania nad stosunkami międzynarodowymi, ale równie silne były głosy o naturalności wojen w relacjach międzyludzkich, a tym samym bezprzedmiotowości dyskursu nad charakterystyką pokoju. Należy jednocześnie zauważyć, że o ile w komunistycznej narracji - w tym w polskiej dyplomacji - operowano już od czasów wystąpienia Wincentego Rzymowskiego podczas sesji plenarnej Zgromadzenia Ogólnego ONZ w Londynie w styczniu 1946 r. pojęciem niepodzielności pokoju, o tyle bardziej wymierne były badania nad bezpieczeństwem strategicznym, które w analizie konfliktów (tj. w opisie ich genezy, istniejących napięć wewnętrznych i zewnętrznych) były bardziej pragmatyczne, zwłaszcza dla ówczesnych decydentów; szerzej zob. Tomasz Pawłuszko, „Teoria bezpieczeństwa a teoria pokoju," w Bezpieczeństwo międzynarodowe. Polska-Europa-Świat. Księga Jubileuszowa dedykowana Profesorowi Ryszardowi Ziębie z okazji czterdziestolecia pracy naukowej, red. Justyna Zając, Agata Włodkowska-Bagan i Marcin Kaczmarski (Warszawa: Wydział Dziennikarstwa i Nauk Politycznych Uniwersytetu Warszawskiego, 2015), 65-70. Wspomniany pragmatyzm uwidacznia się m.in. w polityce Stanów Zjednoczonych, które swoją aktywność zewnętrzną, w tym również na kierunku indochińskim, oparły na kwestii bezpieczeństwa strategicznego USA. 


\section{Elementy sytuacji wojskowej}

1. Doświadczenia militarne ostatnich lat $\mathrm{w}$ Wietnamie wydają się wciąż od nowa potwierdzać oczywisty wniosek, iż założenia amerykańskiej strategii wojskowej okazują się niewykonalne. Stany Zjednoczone - jak zgodnie przyznaje większość fachowej opinii zachodniej - nie są w stanie doprowadzić do wojskowego rozstrzygnięcia konfliktu. Świadczy o tym pośrednio praktyka eskalacji - ciągłego windowania nasilenia i rozszerzania zasięgu działań zbrojnych. Świadczy ona w gruncie rzeczy o tym, że założenia sztabu amerykańskiego uważane w punkcie wyjściowym jako rozwiązania ostateczne, w zetknięciu z rzeczywistością okazują się mylne. ${ }^{18}$ Rodzi to w konsekwencji desperację napędzającą błędne koło eskalacji. Stany Zjednoczone za każdym razem podnoszą stawkę w nadziei odrobienia przegranej. ${ }^{19} \mathrm{~W}$ tej

18 Należy zgodzić się z autorem(ami) materiału, że do czerwca 1966 r. wstępne założenia operacyjne stawiane przed wojskami amerykańskim (od marca 1965 r., tj. od przybycia do Wietnamu Południowego pierwszych regularnych amerykańskich jednostek wojskowych) uległy znacznym przewartościowaniom. Według Piotra Ostaszewskiego było to następstwem braku określenia przez administrację prezydenta Johnsona jasnego oraz spójnego celu obecności sił amerykańskich w Indochinach. Wraz z eskalacją konfliktu w sposób oczywisty dotychczas stosowana strategia wymagała doprecyzowania i zmodyfikowania. Zgodnie z polityką Waszyngtonu w 1965 r. zamierzano swoją aktywność bojową w Wietnamie ograniczyć wyłącznie do ochrony amerykańskich baz i instalacji wojskowych. W rzeczywistości - wobec intensyfikacji działań VC oraz NRV - zlokalizowane w I Korpusowej Strefie Taktycznej (CTZ - Corps Tactical Zone) w Da Nang oddziały US Marine Corps (Korpusu Piechoty Morskiej Stanów Zjednoczonych - USMC) zmuszone zostały już w kwietniu tr. w okolicach Binh Thai walczyć z siłami komunistycznymi, a w sierpniu w ramach operacji „Starlite” rozszerzyć zakres operacyjny swojej obecności militarnej w Wietnamie. Nastąpiło to również w wyniku postanowień konferencji w Honolulu z 20 IV 1965 r., skutkiem których już w czerwcu gen. William Westmoreland otrzymał zgodę na podejmowanie działań o charakterze ofensywnym wykraczających poza dotychczasową strategię obrony własnych instalacji; zob. Ostaszewski, Wietnam, 406, 412-414; William C. Westmoreland, A Soldier Reports (New York: Doubleday, 1976), 135; Pimlott, Wojna, 42; Sacewicz, „Zanim” 366, 368.

19 Twierdzenie o przegrywaniu wojny przez Amerykanów w 1966 r. rozmija się z prawdą. Było wielkim propagandowym nadużyciem. Niewątpliwie sytuacja operacyjna w Wietnamie Południowym nie była wówczas korzystna dla sił „wolnego świata”, niemniej jednak to w $1966 \mathrm{r}$. nastąpiła intensyfikacja ofensywnych działań antykomunistycznych. Według Gabriela Kolko Amerykanie do tego czasu byli bardzo pasywni, prowadząc działania o charakterze defensywnym, przez co pozwolili komunistycznym siłom narzucać tempo, zakres i formy walki; zob. Kolko, Anatomy, 177. Od 1966 r. nastąpiła radykalna i widoczna zmiana amerykańskiego sposobu prowadzenia wojny w Wietnamie Południowym. Przyszedł czas wypracowywania modelu i taktyki walki, prowadzenia działania w oparciu o strategię „szukaj i zniszcz” - co było elementem wojny obliczonej na wyczerpanie przeciwnika. W tym też roku rozpoczęto wielkie zbrojne operacje wymierzone w VC i NRV. Według opracowania wywiadu wojskowego PRL było ich 45; zob. Archiwum Instytutu Pamięci Narodowej w Warszawie (dalej: AIPN), Ministerstwo Spraw Wewnętrznych w Warszawie (dalej: MSW), 01334/633, „Rozwój działań wojennych w Wietnamie. Część III”, Warszawa, 1967 r., 34-38. Od grudnia 1965 r. do końca marca 1966 r. opracowanie Zarządu II Sztabu Generalnego WP wymieniało 27 operacji antykomunistycznych; zob. ibid., 01334/632, „Rozwój działań wojennych w Wietnamie. Część II”, Warszawa, 
jednak rzeczywistości, która wydaje się wykluczać rozwiązanie konfliktu metodami czysto wojskowymi, znajduje odzwierciedlenie krwawy i wyniszczający impas militarny wojny wietnamskiej.

2. a) Historię zmagań zbrojnych ostatnich pięciu lat można z punktu widzenia eskalacji z grubsza podzielić na 5 etapów. W czerwcu $1961 \mathrm{r}$. Amerykanie przejęli bezpośredni nadzór bojowy ${ }^{20}$ nad wojskami Diema, a po wizycie gen. Taylora ${ }^{21} \mathrm{w}$ Południowym Wietnamie w październiku tegoż

czerwiec 1967 r., 28-29; Sacewicz, „Zanim,” 376. Ich rozmiary, operacyjny zakres, wielkość użytych w nich sił, a przede wszystkim skutki wskazywały na wypracowywanie modelu strategii mającej doprowadzić do ostatecznego sukcesu; zob. Jeffrey J. Clark, Advice and Support: The Final Years 1965-1973 (Washington: Center of Military History United States Army, 1988), 8593. Kiedy rozpoczynano realizację wspólnego południowowietnamsko-amerykańskiego planu kampanii na rok 1967, inicjatywa bezapelacyjnie znalazła się po stronie amerykańskiej. Było to bez wątpienia konsekwencją działań podjętych rok wcześniej; zob. Sacewicz, „Zanim,” 373-374, 376; Guenter Lewy, America in Vietnam (Oxford - New York: Oxford University Press, 1978), 67-78; James J. Wirtz, The Tet Offensive. Intelligence failure in war (Ithaca: Cornell University Press, 1994), 42. Wówczas to zainicjowano działania bojowe polegające na próbie przejęcia komunistycznych sanktuariów i odzyskania kontroli nad newralgicznymi obszarami w poszczególnych CTZ; zob. John Prados, „American Strategy in the Vietnam war,” w The Columbia History of the Vietnam War, red. David L. Anderson (New York: Columbia University Press, 2001), 247; AIPN, MSW, 01334/634, „Rozwój działań wojennych w Wietnamie. Część IV: siły lądowe”, Warszawa, 1968 r., 37.

20 Po ustaniu działań zbrojnych na Półwyspie Indochińskim w 1954 r. Francuzi utrzymywali w Wietnamie Południowym Korpus Ekspedycyjny, którego wielkość systematycznie była zmniejszana. W czerwcu 1956 r. francuska misja wojskowa zakończyła swoją działalność, a w lipcu urząd Wysokiego Komisarza do Spraw Indochin został przekształcony w stanowisko ambasadora Republiki Francuskiej w Wietnamie Południowym. Jednocześnie następował wzrost zaangażowania USA w Wietnamie. Uwidoczniło się to m.in. w zwiększeniu się liczebności amerykańskiego personelu wojskowego. W sposób niemalże naturalny prowadziło to do wzięcia przez administrację waszyngtońską pełnej odpowiedzialności za rozwój sytuacji militarno-politycznej w Wietnamie Południowym; szerzej zob. Ostaszewski, Wietnam, 323-324, 332-336; Pentagon Papers, cz. IV.A.4, Evolution of the War: U.S. Training of the Vietnamese National Army 1954-1959, 72-74, dostęp styczeń 26, 2020, https://nara-media-001.s3.amazonaws.com/arcmedia/research/pentagon-papers/Pentagon-Papers-Part-IV-A-4.pdf; William C. Gibbons, U.S., Congress, Senate, Committee on Foreign Relations, The U.S. Government and the Vietnam War: Executive and Legislative Roles and Relationships, cz. 2, 1961-1964 (Washington: U.S. Government Printing Office, 1985).

21 Maxwell Taylor (ur. 1901 - zm. 1987) - w latach II wojny światowej dowódca 82 Dywizji Powietrzno-desantowej (DPD), a następnie od wiosny 1944 r. 101 DPD, komendant Akademii Wojskowej West Point, w latach 1949-1952 dowódca amerykańskich wojsk okupacyjnych w Berlinie, od 1953 r. dowodził 8 Armią amerykańską podczas wojny koreańskiej. W 1955 r. objął funkcję szefa Sztabu Armii Stanów Zjednoczonych, którą sprawował do 1959 r. Po nieplanowanym powrocie z emerytury został w latach 1961-1962 doradcą do spraw wojskowych prezydenta Kennedy'ego, a w latach 1962-1964 przewodniczącym Kolegium Szefów Połączonych Sztabów (Joint Chiefs of Staff - JCS), następnie w 1965 r. był ambasadorem USA w Wietnamie Południowym. Od 1965 r. do 1969 r. kierował Radą Doradczą Wywiadu działającą u boku prezydenta Johnsona. 
roku $^{22}$ rozwinęli tzw. wojnę specjalną ${ }^{23}$, której zadeklarowanym celem była pacyfikacja kraju w ciągu 18 miesięcy. ${ }^{24}$ Liczba amerykańskiego ekspedycyjnego korpusu oficerskiego w Południowym Wietnamie, tzw. doradców, w 1961 r. w porównaniu do roku 1960 podwoiła się do 1346 oficerów $^{25}$, aby pod koniec 1963 r. - według oficjalnych danych - dojść do liczby 16575 oficerów. ${ }^{26}$

22 Mowa o wizycie w Sajgonie w dniach 18 X - 1 XI 1961 r. specjalnych wysłanników Białego Domu, tj. gen. Taylora i Walta Rostowa; zob. Ostaszewski, Wietnam, 355.

23 Memorandum gen. Taylora z października 1961 r. [zob. „Letter from the President's Military Representative (Taylor) to the President, Washington, November 3, 1961," w Foreign Relations United States, 1961-1963, t. 1, Vietnam 1961, red. Ronald D. Landa i Charles S. Sampson (Washington D.C.: United States Government Printing Office, 1988), dostęp styczeń 27, 2020, https://history.state.gov/historicaldocuments/frus1961-63v01; Jack Schulismon, History of the Joint Chiefs of Staff. The Joint Chiefs of Staff and the War in Vietnam 1960-1968. Part 1 (Washington D.C.: Office of Joint History, Office of the Chairman of the Joint Chiefs of Staff, 2011), 130-133] proponujące powołanie 6-8 tys. kontyngentu wojskowego w celu wsparcia działań obronnych władz południowowietnamskich (oficjalnie pod pretekstem naprawy skutków powodzi w dolinie Mekongu), wywarło mocny wpływ na modyfikację przez prezydenta Kennedy'ego i jego administrację dotychczasowej formuły polityczno-wojskowego wsparcia dla Sajgonu. Analizując propozycje gen. Taylora, Departament Obrony wskazywał, że wysłanie wojsk do Wietnamu będzie koniecznością gwarantującą uzyskanie stawianych sobie celów, tj. ochrony rządów w Sajgonie, ale też będzie niosło ze sobą konieczność przeprowadzenia w nieodległej przyszłości interwencji zbrojnej większym kontyngentem sił aniżeli tylko 8 tys., tj. minimum 3 i więcej amerykańskich dywizji. Sekretarz Robert McNamara wskazywał na gotowość wysłania do Azji Południowo-Wschodniej od 6 do 8 dywizji; Schulismon, History, 135-136. Nie decydując się jeszcze na regularną interwencję zbrojną w Wietnamie, w styczniu 1962 r. Amerykanie utworzyli Centrum Militarnego Doradztwa w Wietnamie (MACV); zob. Clark, Advice, 49 i n.; Ostaszewski, Wietnam, 357; Schulismon, History, 175-176. Ponadto mając świadomość asymetryczności konfliktu w Azji Południowo-Wschodniej utworzyli oni Grupę Specjalną (Special Group - Counter-Insurgency - SGCI); zob. „National Security Action Memorandum No. 124, 18 January 1962,” w Pentagon Papers, cz. V.B.4, The Kennedy Administration. Book 2, 442-443, dostęp styczeń 26, 2020, https://nara-media-001.s3.amazonaws.com/arcmedia/research/pentagon-papers/ Pentagon-Papers-Part-V-B-4-Book-II.pdf; Ostaszewski, Wietnam, 357; FM 3-18. Special Forces Operations, Headquarters Department of the Army (Washington D.C.: Create Space Independent Publishing Platform, 2014), 1-7.

24 Ostaszewski, Wietnam, 355-356. Na temat zgody Białego Domu na działania sił specjalnych w Wietnamie w celu wsparcia władz sajgońskich zob. „National Security Action Memorandum No. 104, 13 October," w Pentagon Papers, cz. V.B.4, The Kennedy Administration. Book 1, 328, dostęp styczeń 26, 2020, https://nara-media-001.s3.amazonaws.com/arcmedia/ research/pentagon-papers/Pentagon-Papers-Part-V-B-4-Book-I.pdf.

25 Błąd: powinno być 3146 żołnierzy i oficerów. AIPN, MSW, 01334/634, „Rozwój działań wojennych w Wietnamie. Część IV: siły lądowe”, Warszawa, 1968 r., 44.

26 W 1960 r. w Wietnamie Południowym przebywało 875 instruktorów wojskowych, w 1964 r. było ich już ponad 23 tys.; Pimlott, Wojna, 178. W 1962 r. w ramach operacji "Hamlet” systematycznie wzmacniano amerykański kontyngent wojskowy w Wietnamie. Według danych JCS w kwietniu 1962 r. Stany Zjednoczone Ameryki dysponowały liczbą 1351 indywidualnych doradców wojskowych u boku sił południowowietnamskich. Liczba 
Założenia „wojny specjalnej”27, w centrum której stało uwięzienie ludności wiejskiej, głównego rezerwuaru sił powstańczych, w tzw. wsiach strategicznych ${ }^{28}$,

ta nie obejmowała 800 żołnierzy sił specjalnych. Pod koniec 1962 r. liczba amerykańskich doradców wojskowych, oficerów i pracowników wywiadu wojskowego oraz przedstawicieli personelu technicznego wynosiła 9865 osób; Ostaszewski, Wietnam, 359; The Text of the Contoversial Republican White Paper. The war in Vietnam. Prepared by the Staff of the Senate Republican Policy Committee (Washington D.C.: Public Affairs Press, 1967), 59. Jednocześnie południowowietnamscy żołnierze (3296 osób) w latach 1950-1959 byli szkoleni w USA oraz w krajach „wolnego świata” (747 osób); Pentagon Papers, cz. IV.A.4, 89. W sierpniu 1963 r. w Wietnamie Południowym stacjonowało 16201 amerykańskich doradców wojskowych, we wrześniu było ich 16480 , w październiku 16732, w listopadzie 16456, zaś w grudniu 15732. W grudniu 1964 r. ich liczba przekroczyła 23 tys. W 1963 r., na co wskazują dokumenty amerykańskiej administracji, planowano zmniejszenie własnego potencjału ludzkiego w Wietnamie w 1965 r. do poziomu 5,9 tys. Według ustaleń sekretarza obrony McNamary i gen. Taylora do końca 1963 r. miano wycofać z Wietnamu 1 tys. amerykańskich doradców wojskowych. Był to jednak zabieg czysto propagandowy, swoista rachunkowość, która $\mathrm{z}$ racji rotacji składu wojskowego de facto w rzeczywistości nie zmieniła liczby doradców wojskowych w Wietnamie Południowym; zob. „Summary," w Pentagon Papers, cz. IV.B.4, 1, 4; Pentagon Papers, cz. B.IV.4, Evolution of the War. Counterinsurgency: Phased withdrawal of U.S. Forces 1962-1964, 30, 44, 53, dostęp styczeń 26, 2020, https://www.archives.gov/research/pentagon-papers. Stan liczebny sił amerykańskich stacjonujących i walczących w Wietnamie był przedmiotem zainteresowania wywiadu wojskowego PRL. Według jego opracowań w 1960 r. w Wietnamie Południowym znajdowały się 773 osoby doradczego personelu wojskowego, w 1961 r. liczba ta wzrosła do 3164 osób, w 1962 r. było już 9865 żołnierzy, w 1963 r. 16,5 tys., w 1964 r. 23 tys., w 1965 r. wraz z przybyciem regularnych jednostek wojsk amerykańskich było to 181250 żołnierzy i w 1966 r. 390400 żołnierzy; zob. AIPN, MSW, 01334/634, „Rozwój działań wojennych w Wietnamie. Część IV: siły lądowe”, Warszawa, 1968 r., 44. Z kolei według załącznika nr 16: „Stan liczbowy wojsk amerykańskich w Wietnamie Południowym w latach 1960-1973" zamieszczonego w opracowaniu Zarządu II SG z 1974 r. w grudniu 1960 r. było 885 amerykańskich żołnierzy/doradców, w grudniu 1961 r. - 3205, a pod koniec 1963 r. 16,3 tys.; zob. ibid., 01791/24, t. 2, „Rozwój działań wojennych na Półwyspie Indochińskim w latach 1968-1974 (załączniki)", Warszawa, 1974 r., 23. Niemalże tożsame dane - poza niewielkimi różnicami w 1965 r. i 1966 r. - podawał The Text of the Controversial Republican, 59.

27 Jednym $z$ elementów prowadzonej wojny specjalnej było zezwolenie na stosowanie przez administrację Białego Domu defoliantów w celu obniżenia wzrostu lasów tropikalnych w Wietnamie, przy czym informowano społeczność lokalną, a także opinię publiczną o nieszkodliwości defoliantu, co w przyszłości w ramach operacji „Agent Orange” okazało się wielkim kłamstwem; „Telegram from the Department State to the Embassy in Vietnam, Washington, December 14, 1961," w Foreign Relations United States, dostęp styczeń 27, 2020, https://history.state.gov/historicaldocuments/frus1961-63v01. W latach 1965-1971 defoliantem opryskano 3,2\% ogólnej powierzchni Wietnamu Południowego, w tym 46,4\% ogólnej powierzchni lasów tropikalnych. Podczas stosowania środka „Orange” w samym tylko 1966 r. zniszczeniu uległo ponad 103 tys. akrów (41,5 tys. ha) ziemi uprawnej; zob. Lewy, America, 258.

28 Mowa o projekcie strategicznym o kryptonimie „Hamlet”, zakładającym powstanie wiosek strategicznych, do których miano relokować dobrowolnie lub pod przymusem miejscową ludność. Wzorując się na malezyjskich doświadczeniach brytyjskiego gen. Roberta Thompsona, dążono do odizolowania ludności od wpływów VC. We wrześniu 1962 r. funkcjonowało ponad 
doznały zupełnego fiaska. ${ }^{29}$ Wiadomym znakiem klęski było obalenie reżymu Diema 1 listopada 1963. ${ }^{30}$

b) Miesiąc przed załamaniem się rządów Diema, 2 października 1963 r., Biały Dom w oświadczeniu powołującym się na orzeczenie sekretarza obrony McNamary ${ }^{31}$ i gen. Taylora, zapowiedział ostateczne zwycięstwo w końcu 1965 r. i nawet wycofanie części amerykańskiego personelu wojskowego jeszcze do końca 1963 r. ${ }^{32}$ Rok 1964 okazał się jednak, z punktu widzenia działań zbrojnych, rokiem zwrotnym. Siły powstańcze przejęły zdecydowanie inicjatywę $\mathrm{w}$ swe ręce, a marionetkowy reżim sajgoński znalazł się na granicy zupełnego rozkładu i upadku. ${ }^{33}$

3,2 tys. wiosek, w których skupiono ponad 4,3 mln osób, zaś w budowie znajdowało się kolejnych 2 tys. strategicznych osad. W kwietniu 1963 r. oficjalnie funkcjonowało ich 6 tys. Należy jednak podkreślić, że liczba powstałych i działających we wrześniu 1962 r. osad była wykonaniem planu na poziomie 30\%. Pierwotnie zakładano uruchomienie 11316 osad. Pokazywało to, że projekt już na samym początku swojego istnienia w praktyce znacząco odbiegał od pierwotnej koncepcji nakreślonej przez Rogera Hilsmana - dyrektora Biura Wywiadu i Badań Departamentu Stanu - w przekazanym prezydentowi Kennedyemu elaboracie pt. „Strategiczna koncepcja dla Wietnamu Południowego” (z 2 II 1962 r.); szerzej na temat projektu „Hamlet” i operacji „Sunrise” zob. Pentagon Papers, cz. IV.B.2, Evolution of the War. Counterinsurgency: The strategic Hamlet Program 1961-1963, 28, 30, 31, dostęp styczeń 26, 2020, https://naramedia-001.s3.amazonaws.com/arcmedia/research/pentagon-papers/Pentagon-Papers-Part-IV-B-2.pdf; Ostaszewski, Wietnam, 43-344; Pimlott, Wojna, 30.

29 Projekt $\mathrm{z}$ powodu fatalnej realizacji, korupcji południowowietnamskich urzędników i wojskowych, zakończył się klęską zarówno w wymiarze politycznym - zwiększył nienawiść społeczną do rządów w Sajgonie, jak i militarnym - wiele osad z powodu braku odpowiedniego zabezpieczenia kontrwywiadowczego stało się komunistycznymi enklawami, które siły południowowietnamskie oraz amerykańskie były zmuszone odbijać w ciężkich akcjach bojowych, czego najbardziej znanym w literaturze przykładem jest bitwa o przysiółek strategiczny Ap Bac, stoczona w styczniu 1963 r.; zob. Przemysław Benken, Ap Bac 1963 - Binh Gia 1964. Dwie bitwy, które zmienity bieg wojny w Wietnamie (Zabrze - Tarnowskie Góry: Inforteditions, 2018), 10-46; Schulismon, History, 277-280.

30 Na temat sytuacji polityczno-militarnej w Wietnamie Południowym, a tym samym genezy i następstw zamachu stanu, który doprowadził do obalenia i zamordowania Diema, zob. Ostaszewski, Wietnam, 365-372; „Chronology,” w Pentagon Papers, cz. IV.B.5, Evolution of the War. Counterinsurgency. The Kennedy Commitments 1961-1963: The Overthrow of Ngo Dinh Diem. May-November, 1963, XXVII-XXXI, dostęp styczeń 26, 2020, https://nara-media-001.s3.amazonaws.com/arcmedia/research/pentagon-papers/Pentagon-Papers-Part-IV-B-5.pdf.

31 Robert McNamara (ur. 1916 - zm. 2009) - amerykański polityk, w latach 1961-1968, tj. podczas prezydentury Johna F. Kennedyego oraz Lyndona B. Johnsona, sekretarz obrony USA, następnie do 1981 r. kierował Bankiem Światowym.

32 „Memorandum for the President, «Report of McNamara-Taylor Mission to South Vietnam,» 2 October 1963” w The Pentagon, 2:751-766, dostęp styczeń 26, 2020. https://www. mtholyoke.edu/acad/intrel/pentagon2/doc142.htm; "Chronology," w Pentagon Papers, cz. IV.B.5, XXI.

33 Intensyfikacja działań komunistycznych przeciwko władzom sajgońskim oraz amerykańskiemu personelowi wojskowemu była widoczna już od 1957 r., kiedy to po rozbiciu 
c) W tej sytuacji Amerykanie zdecydowali się na trzeci etap eskalacji. W październiku 1964 r. prezydent Johnson podjął decyzję o zbombardowaniu Demokratycznej Republiki Wietnamu ${ }^{34} /$ zob. Richard Dudman

militarnych formacji związanych z sektami Hoa Hao i Cao Dai zostały zasilone szeregi VC, który wówczas przeszedł do zdecydowanej ofensywy, dokonując kilkuset ataków na instalacje rządowe. W kolejnych latach nacisk VC zwiększał się, przez co sytuacja polityczno-militarna w Wietnamie Południowym uległa pogorszeniu. W latach 1959-1960 partyzantka komunistyczna miała dokonać ponad 2 tys. ataków, zaś według raportu Edwarda Lansdala w 1961 r. kontrolowała ona 58\% terytorium Wietnamu Południowego. Ponadto w 1963 r. Hanoi podjęło decyzję o intensyfikacji działań przeciwko władzom w Sajgonie. Wzrost był bardzo odczuwalny - o ponad $50 \% \mathrm{w}$ stosunku do roku poprzedniego. To $\mathrm{z}$ kolei wpłynęło na stanowisko sekretarza McNamary, wyrażone w memorandum skierowanym do Prezydenta USA 21 XII 1963 r., o bezwzględnej potrzebie wsparcia sajgońskich władz. McNamara stwierdzał, że bez pomocy Stanów Zjednoczonych w ciągu dwóch do trzech miesięcy siły komunistyczne przejmą kontrolę nad całym państwem; „Secretary of Defense, Robert McNamara, Memorandum for the President, "Vietnam Situation,» 21 December 1963" w The Pentago, 3:494-496, dostęp luty 3, 2020, https://www.mtholyoke.edu/acad/intrel/pentagon3/doc156.htm; Pentagon Papers, cz. IV.B.4, 44; Ostaszewski, Wietnam, 339, 353, 374. Należy podkreślić, że w 1963 r. armii południowowietnamskiej udało się powstrzymać napór przeciwnika, niemniej jednak nie oznaczało to zmniejszenia nacisku ze strony komunistów. Na przełomie 1963 i 1964 r. miała miejsce bitwa o Binh Gia, która stanowiła istotną cezurę $\mathrm{w}$ historii amerykańskiego zaangażowania się w Wietnamie, de facto powstrzymując i marginalizując coraz bardziej powszechne i nasilające się w amerykańskich kołach decyzyjnych głosy o wycofaniu jednostek wojskowych z Wietnamu Południowego. Szerzej na temat przebiegu, a przede wszystkim następstw walk w rejonie Binh Gia zob. Benken, Ap Bac 1963, 47-88. Na istotny wpływ zwycięstwa komunistów pod Binh Gia na podjęcie decyzji o wysłaniu regularnych oddziałów wojsk amerykańskich do Wietnamu wskazywał m.in. Herbert Schandler, zob. Hebert Y. Schandler, America in Vietnam: The War That Couldn't Be Won (Lanham: Rowman \& Littlefield Publishers, 2009), 57-58; Sacewicz, „Zanim,” 367.

34 Decyzję o przeprowadzeniu systematycznych bombardowań na Wietnam Północny prezydent Johnson podjął 27 XI 1964 r. podczas posiedzenia Narodowej Rady Bezpieczeństwa. Naloty były pokłosiem wdrożenia w życie koncepcji dalszych działań zbrojnych w Wietnamie, przedłożonej prezydentowi we wrześniu $1964 \mathrm{r}$. przez gen. Taylora. Ten opowiadał się za kontynuacją operacji „De Soto”, dalszymi lotami wywiadowczymi nad Wietnamem Północnym oraz koniecznością stałych działań zbrojnych w Laosie, a także nalotów odwetowych na DRW. Na decyzję prezydenta wpływ miało również spotkanie sekretarza obrony McNamary, które odbyło się 27 XI 1964 r., w którym uczestniczyli m.in. gen. Taylor, szef Połączonych Sztabów gen. Joseph Wheeler, jak również doradca prezydenta McGeorge Bundy. Analizie poddano opinię o sytuacji w Wietnamie przedstawioną przez gen. Westmorelanda, który to skłaniał się do intensyfikacji działań zbrojnych, ale nie wcześniej niż za pół roku, kiedy to baza materiałowa i osobowa dla amerykańskiej aktywności zostanie wzmocniona. Jego stanowisko uznano za zbyt optymistyczne. Zarówno ambasador - gen. Taylor, jak i sekretarz McNamara wskazywali, że wobec wewnętrznej, wielce skomplikowanej i niestabilnej sytuacji w Republice Wietnamu administracja amerykańska nie ma czasu na żadną zwłokę. Opowiadano się więc za opcją C, chociaż i tak sam gen. Taylor nie dawał wiary, czy ona wystarczy do poprawienia polityczno-militarnej pozycji władz sajgońskich. Zwłaszcza że 10 dni wcześniej grupa robocza Narodowej Rady Bezpieczeństwa opowiadała się za wariantem B; zob. Pentagon Papers, cz. IV.C.2.c, Evolution of the War. Direct Action. The Johnson Commitments 1964-1968. Military pressures against North Vietnam, November-December 


\section{„Military Policy in Wietnam”, Current History, luty 1966 r./35, którą pod pre- tekstem odwetu ${ }^{36}$ zaczął realizować od lutego $1965 .{ }^{37}$ Równolegle od 19 lu- tego 1965 r. zostały zainicjowane barbarzyńskie bombardowania terenów}

1964, part III: Military pressures against North Vietnam: November 1964 - January 1965, V, $\mathrm{X}, 27$, dostęp styczeń 26, 2020, https://nara-media-001.s3.amazonaws.com/arcmedia/research/ pentagon-papers/Pentagon-Papers-Part-IV-C-2c.pdf; Ostaszewski, Wietnam, 400. Na temat modyfikacji koncepcji działalności USA w Wietnamie, czyli tak zwanych opcji A, B i C, zob. szerzej Ostaszewski, Wietnam, 18 i n. Wariant pierwszy - w dokumentach określany jako opcja A - zakładał prowadzenie działań morskich oraz lądowych w celu uwzględnienia natychmiastowych represji za ataki na obiekty i jednostki USA, przy jednoczesnym twardym kursie na niezawieranie żadnych układów z komunistami, chyba że nastąpi pełna zgoda na przestrzeganie amerykańskich interpretacji ładu pogenewskiego. Wariant drugi - tzw. opcja B - zakładał kontynuację obecnych działań antykomunistycznych połączonych $\mathrm{z}$ atakami bombowymi na DRW. Opcja C oznaczała lżejsze, wojskowe naciski przeciwko DRW, przy jednoczesnym realizowaniu dotychczasowych działań mających na celu wzmocnienie władz w Sajgonie. Na listopadową decyzję prezydenta ogromny wpływ miała akcja komunistów na lotnisku Bien Hoa, w wyniku której śmierć poniosło czterech amerykańskich żołnierzy; zob. Ostaszewski, Wietnam, 400. Na temat koncepcji użycia sił zbrojnych w Wietnamie zob. Graham A. Cosmas, History of the Joint Chiefs of Staff. The Joint Chiefs of Staff and the War in Vietnam, 1960-1968. Part II (Washington D.C.: Office of Joint History, Office of the Chairman of the Joint Chiefs of Staff, 2012), 175-180.

35 Richard Dudman, „Military Policy in Vietnam,” Current History 50, nr 294 (1966): 91-97.

36 Bezpośrednim pretekstem do przeprowadzenia bombardowań instalacji na terenie Wietnamu Północnego był atak VC dokonany 6 II 1965 r. na amerykańskie koszary wojskowe w Pleiku. W jego wyniku śmierć poniosło 9 amerykańskich żołnierzy, ponad 100 zostało rannych. W odwecie następnego dnia - 7 II 1965 r. - 62 samoloty amerykańskich i południowowietnamskich sił powietrznych uderzyły na północnowietnamskie koszary w Dong Hoi. Rozpoczęto realizację operacji „Flaming Dart I”, tj. odwetowych ataków lotniczych na pozycje komunistyczne. 10 lutego VC ponownie zaatakował. Tym razem celem była baza w Qui Nhon. W wyniku ataku śmierć poniosło 23 Amerykanów, a ponad 100 zostało rannych. Stało się to podstawą do przeprowadzenia operacji odwetowej o kryptonimie „Flaming Dart II"; zob. Łukasz M. Nadolski, Walki powietrzne nad Wietnamem Pótnocnym w latach 1965-1968 na tle operacji Rolling Thunder, t. 1, Lata 1965-1967 (Toruń: Wyd. Nauk. Uniwersytetu Mikołaja Kopernika, 2016), 112-119; Ostaszewski, Wietnam, 403-404.

3711 II 1965 r. prezydent Johnson podpisał rozkaz rozpoczęcia operacji „Rolling Thunder”, tj. bombardowań Wietnamu Północnego pomiędzy 17 a 19 równoleżnikiem. Rozpoczęła się ona 2 III 1965 r.; szerzej zob. Nadolski, Walki, 1:120 i n.; Nadolski, Walki powietrzne nad Wietnamem Pótnocnym w latach 1965-1968 na tle operacji Rolling Thunder, t. 2, Lata 1967-1968 (Bydgoszcz: Muzeum Wojsk Lądowych, 2018), passim; Ostaszewski, Wietnam, 404; Katarzyna Gruszka, „Rolling Thunder - pierwsza amerykańska ofensywa powietrzna w Wietnamie," w Studia nad wojnami w Indochinach, t. 1, red. Benken (Oświęcim: Napoleon V, 2013), 122-141; David L. Anderson, The Columbia Guide to the Vietnam War (New York: Columbia University Press, 2002), 46; Bogdan Stech, Wojna powietrzna nad Wietnamem (Warszawa: „Lampart”, 1995), passim; Ulysses S. Grant Sharp, Report on the war in Vietnam, as of 30 June 1968. Section I: Report on air and naval campaigns against North Vietnam and Pacific Command-wide support of the war, June 1964 - July 1968 (Washington D.C.: United States Government Printing Office, 1969), 16 i n.; Clark, Advice, 49 i n. 
wyzwalanych w Południowym Wietnamie. ${ }^{38}$ Amerykańskie koła wojskowe liczyły na radykalny skutek. Miały nadzieję rzucić Wietnam na kolana w ciągu paru tygodni, czy nawet dni /tamże/. Nadzieje te całkowicie zawiodły. Okazało się, że im większe było zastosowanie siły ze strony agresorów, im brutalniejsze środki, tym bardziej rósł opór narodowy Wietnamczyków. Prawidłowości wojny obalały wszelkie kalkulacje sztabowców amerykańskich.

d) Nastąpił czwarty etap eskalacji. W czerwcu 1965 r. wojska amerykańskie, które dla ochrony baz i okupacji rejonów strategicznych zaczęły napływać do Wietnamu Południowego w znacznych ilościach ${ }^{39}$, zaangażowały się bezpośrednio $\mathrm{w}$ walkach zbrojnych na dużą skalę $\mathrm{z}$ siłami powstańczymi. ${ }^{40}$ Stany Zjednoczone wbrew przyjętemu od czasu wojny w Korei kardynalnemu założeniu, nakazującemu unikanie zaangażowania militarnego na lądzie azjatyckim ${ }^{41}$, uwikłały się w taką właśnie wojnę. W rzeczywistości, klasyczna

38 Informacja nieprawdziwa, bowiem bombardowania dotyczyły celów w Wietnamie Północnym i były przeprowadzane w ramach operacji „Rolling Thunder”, która pierwotnie miała rozpocząć się 20 II 1965 r., ale z powodu przewrotu politycznego w Sajgonie została odwołana. W konsekwencji pierwsze naloty miały miejsce dopiero 2 III 1965 r.; zob. Nadolski, Walki, 1:126 i n. Z kolei siły powietrzne amerykańskiej marynarki wojennej w ramach „Rolling Thunder” rozpoczęly naloty 15 III 1965 r.; Norman Polmar i Edward J. Marolda, The U.S. Navy and the Vietnam War. Naval Air War. The Rolling Thunder Campaign (Washington D.C.: Naval History \& Heritage Command, Naval Historical Foundation, 2015), 5 i n.

39 Na dzień 7 VI 1965 r. na terenie Wietnamu Południowego stacjonowało ok. 50 tys. amerykańskich żołnierzy, z czego 21,5 tys. z US Army (Armii Stanów Zjednoczonych), 16,5 tys. z USMC, 9,5 tys. z Sił Powietrznych Stanów Zjednoczonych (US Air Force - USAF) oraz 3,5 tys. z Marynarki Wojennej Stanów Zjednoczony (US Navy); Chronology of Wietnam conflict [pdf]; Ostaszewski, Wietnam, 411. Nieco inne liczby podaje opracowanie wywiadu wojskowego PRL z 1974 r. Według Zarządu II SG WP na dzień 13 VI 1965 r. w Wietnamie Południowym stacjonowało: 24 tys. żołnierzy US Army, 3,5 tys. US Navy, 9,5 tys. USAF i 16,5 tys. USMC. Łącznie 53,5 tys. amerykańskich żołnierzy. Na koniec grudnia $1965 \mathrm{r}$. liczby te przedstawiały się następująco: US Army - 116,8 tys., US Navy - 8,4 tys., USAF - 20,6 tys., USMC - 38,2 tys. oraz Straż Wybrzeża - 300. Łącznie na terenie Wietnamu Południowego znajdowało się 184,3 tys. amerykańskich żołnierzy; zob. AIPN, MSW, 01791/24 t. 2, „Rozwój działań wojennych na Półwyspie Indochińskim w latach 1968-1974 (załączniki)", Warszawa, 1974 r., 23.

4020 IV 1965 r. podczas konferencji w Honolulu zadecydowano o wysłaniu dodatkowych 75 tys. amerykańskich żołnierzy do Wietnamu, a w konsekwencji do zarzucenia strategii wyłącznie obrony instalacji i baz amerykańskich, na rzecz podjęcia bardziej energicznych działań wobec sił przeciwnika. To z kolei wiązało się z próbami oczyszczenia terenu z oddziałów komunistycznych i odzyskiwania go dla władz sajgońskich. Już 26 VI 1965 r. gen. Westmoreland otrzymał zezwolenie na podejmowanie działań ofensywnych; Westmoreland, A Soldier, 135 i n.; Pimlott, Wojna, 42; Ostaszewski, Wietnam, 412-414.

${ }^{41}$ Nie było takiego oficjalnego, rządowego i determinującego amerykańską politykę zewnętrzną założenia. Warto jednak podkreślić, że znamienici eksperci od spraw międzynarodowych coraz częściej wyrażali krytyczne opinie o militarnym zaangażowaniu się USA w Wietnamie. George F. Kennan od samego początku przestrzegał administrację prezydencką przed prowadzeniem wojny na peryferiach, która $z$ racji oddalenia teatru działań wojennych od własnej bazy, przy jednoczesnych bezpośrednich i znaczących siłach ludzkich 
teza strategów amerykańskich o niebezpieczeństwach wojny lądowej w Azji sprawdziła się. W raporcie senackiej grupy badawczej pod przewodnictwem leadera większości demokratycznej senatora Mansfield[a], opublikowanym w pierwszych dniach stycznia $1966 \mathrm{r}^{42}$, stwierdza się, że „masowe wprowadzenie/do Wietnamu Południowego/ sił amerykańskich i przystąpienie do walk stępiło, ale nie odwróciło ofensywy Viet Congu. Ci ostatni odpowiedzieli na wzrost roli amerykańskiej wzmocnieniem sił własnych przez rekrutację lokalną na Południu i posiłki z Północy oraz ogólne wzmożenie działalności wojskowej. W rezultacie linie podziału w Południowym Wietnamie pozostają $\mathrm{w}$ zasadzie $\mathrm{w}$ tym samym miejscu, jak w punkcie wyjściowym zwiększonego amerykańskiego zaangażowania". ${ }^{43}$ Co więcej, ponieważ zaplecze ludzkie sił powstańczych na lądzie azjatyckim jest niezmierzone ${ }^{44}$, senator Mansfield doszedł do wniosku, że Stany Zjednoczone znalazły się „W sytuacji wojskowej o otwartych możliwościach w kierunku ogólnej wojny na lądzie azjatyckim". Szczególnie znamienne jest stwierdzenie Mansfielda, że siły powstańcze /obliczone na $200-250$ tysięcy ludzi $/{ }^{45} \mathrm{w}$ przeważa-

przeciwnika, z każdym rokiem będzie wojną nie do wygrania. Przeciwnikiem zaangażowania się Ameryki w Wietnamie był także gen. Douglas MacArthur. Stał on na stanowisku, że polityczne ograniczenia uniemożliwią wojskowym skuteczne wykorzystanie posiadanych sił i potencjału, a w konsekwencji negatywne skutki takiego stanu rzeczy będą dla Ameryki bardziej odczuwalne, aniżeli miało to miejsce w przypadku wojny w Korei.

42 Zob. „Text of Mansfield Panel's Conclusions,” The New York Times, styczeń 8, 1966.

43 Na temat stanu operacyjnego posiadania wojsk amerykańskich i ich przeciwników zob. Ahern, CIA and the Generals, 37; Ahern, CIA and Rural, 173.

44 Wietnam Północny korzystał z wielkiego wsparcia udzielonego mu przez władze komunistycznej Chińskiej Republiki Ludowej (ChRL). W szczytowym okresie zaangażowania ChRL w wietnamską wojnę, tj. w roku 1967 na terenie DRW znajdowało się ponad 170 tys. żołnierzy armii chińskiej. Do tego wielotysięczna masa robotników z Chin gwarantowała obsadę personalną w zakładach przemysłowych i rolnictwie. W konsekwencji Hanoi mogło dokonywać przerzutu większych sił północnowietnamskich na południe od 17 równoleżnika, bez uszczerbku dla własnego bezpieczeństwa militarnego i gospodarki; zob. Li Xiaobing, A History of the Modern Chinese Army (Lexington: The University Press of Kentucky, 2007), 217 i n.; Chen Jian, „China's Involvement in the Vietnam War, 1964-69," The China Quarter$l y$, nr 142 (1995): 356-387.

45 Według ustaleń amerykańskiego wywiadu z 1967 r., a więc z okresu, kiedy zaangażowanie VC w działania wojenne - w przeddzień Ofensywy Tết - było największe, odzwierciedlające szczyt mobilizacyjnych i aprowizacyjnych możliwości komunistycznej partyzantki w Wietnamie Południowym, dane te były znacznie niższe. Opierając się na zdobytych dokumentach kierownictwa komunistycznego podziemia, uważano że w 1966 r. partyzanci dysponowali siłą od 170 do 180 tys. ludzi. Weryfikacja tych informacji, nawet przy uwzględnieniu niemożności dokładnego określenia zasięgu terytorialnego operowania oddziałów wroga, spowodowała, że w $1967 \mathrm{r}$. w najbardziej zawyżonych zestawieniach operowano już liczbą od 70 do 90 tys. partyzantów; "Capabilities of the Vietnamese Communists for Fighting in South Vietnam, 13 November 1967," w Estimative, 444; Sacewicz, „Zanim,” 387. Liczba ta w kolejnych miesiącach wzrosła. W sierpniu 1967 r. w dokumencie CIA analizującym strukturę, metody i możliwości rekrutacji, 
jącej większości rekrutują się spośród ludności Południowego Wietnamu. Ilość posiłków z Północy raport ocenia na zaledwie 14 tysięcy żołnierzy. ${ }^{46}$ Raport dalej zaznacza: chociaż nominalnie większość ludności Wietnamu Południowego pozostaje pod kontrolą rządu sajgońskiego, w rzeczywistości jednak „panowanie w rejonach wiejskich pozostaje w znacznej mierze w rękach Viet Congu”. Stany Zjednoczone i siły południowowietnamskie - komentował „US News and World Report” z 24 stycznia 1966 r. $^{47}$ - zachowały terytorium mniejsze niż posiadały przed rokiem. ${ }^{48}$ Tzw. rejony spacy-

ale także i morale sił VC informowano, że całościowy komunistyczny kontyngent bojowy na południu wynosi 121 tys. osób, z czego 66 tys. w jednostkach regularnych NVA, 55 tys. w strukturach VC i w oddziałach Sił Lokalnych; zob. „Problems of Viet Cong Recruitment and Morale, 3 August 1967," w Estimative, 2. Oczywiście trzeba mieć na uwadze, że operowano danymi szacunkowymi, w konsekwencji różne raporty amerykańskich służb wywiadowczych podawały inne liczby, m.in. raporty CIA wskazywały, że w październiku 1967 r. siły komunistyczne na terenie Wietnamu Południowego, złożone zarówno z jednostek NVA, jak i oddziałów VC, liczyły w sumie 118 tys. żołnierzy; „Capabilities of the Vietnamese Communists,” 432, 441. Należy jednak zauważyć, że na całościowy komponent sił komunistycznych operujących w Wietnamie Południowym składały się nie tylko oddziały VC i NVA, ale także jednostki nieregularne, tworzące m.in. siatkę terenową sił komunistycznych, którą przed 31 X 1967 r. oceniano na ponad 112 tys., jak również ok. 40 tys. formacje logistyczno-aprowizacyjne tzw. VC/NVA. Według obliczeń Thomasa Thayera całość sił komunistycznych obejmowała ponad 290 tys. osób; Thomas C. Thayer, War without Fronts. The American experience in Vietnam (Annapolis: Naval Institute Press, 2016), 31. Przy tak szerokim, całościowym postrzeganiu sił komunistycznych wielkości podawane przez Mansfielda zdawały się być prawdziwe. Zbliżone liczby odnajdujemy m.in. w opracowaniach wywiadu wojskowego PRL; zob. AIPN, MSW, 01521/718 t. 3, „Zbiór wiadomości o działaniach wojennych w Wietnamie”, z. 6, Warszawa, 1967 r., 19; Sacewicz, „Zanim,” 388.

46 Dane amerykańskiego wywiadu określały, że w 1965 r. siły północnowietnamskie operujące na południe od 17 równoleżnika stanowiły ekwiwalent 55 batalionów, tj. ok. 54 tys. ludzi; Thayer, War, 31, 33; „Capabilities of the Vietnamese Communists," 435, 441; Sacewicz, „Zanim," 387.

47 „The untold Story of Vietnam War," US News and World Report, styczeń 24, 1966, 29 i n.

48 Informacja nie do końca odzwierciedlająca stan faktyczny. Niewątpliwie w 1966 r. wojskom amerykańskim i ich sojusznikom nie udało się opanować obszarów dotychczas kontrolowanych przez komunistów, ale też nie oznaczało to radykalnego zwiększenia stanu posiadania VC, a tym samym amerykańskiej klęski. Sytuacja wciąż była bardzo dynamiczna. O ile w $1962 \mathrm{r}$. i w 1963 r. VC nie kontrolował połowy terytorium Wietnamu Południowego, zob. Ahern, CIA and the Generals, 100; Clayton D. Laurie i Andres Vaart, „CIA and the Wars in Southeast Asia 1947-1975," Studies in Intelligence. Journal of the American Intelligence Professional, (sierpień 2016), s. 4, to już na przełomie 1964 r. i 1965 r. - na co wskazywały także opracowania i raporty sytuacyjne CIA - ponad połowa terytorium Wietnamu Południowego znajdowała się pod kontrolą sił komunistycznych lub też nie była dostatecznie zabezpieczona przez siły sajgońskie i amerykańskie; zob. Ahern, CIA and the Generals, 173. Sytuacja uległa zmianie po napływie sił zbrojnych „wolnego świata”. W wyniku przeprowadzonych operacji bojowych w $1966 \mathrm{r}$. i w 1967 r. komuniści kontrolowali przede wszystkim tzw. sanktuaria, co oznaczało, że stan ich posiadania w stosunku do roku 1964 i 1965 uległ znacznemu pomniejszeniu. Zwiększyła się liczba obszarów neutralnych, komunistyczne sanktuaria według informacji polskiego wywiadu wojskowego zlokalizowane były wówczas w okolicach Sajgonu, zwłaszcza w pobliżu granicy 
fikowane nie są bezpieczne, a głośno reklamowane amerykańskie kampanie antypartyzanckie nie ruszyły z miejsca". ${ }^{9}$

e) Te okoliczności skłoniły Waszyngton pod koniec 1965 r. i w styczniu 1966 r. do czasowej przerwy w bombardowaniach ${ }^{50}$, które w ogólnym wyczuciu zrodziły dla Stanów Zjednoczonych "znacznie więcej politycznej i moralnej szkody, niż korzyści wojskowych” /,The New York Times”, 7 marca 1966 r. $/^{51}$ Przerwa okazała się konieczna, aby gestem pokojowym uspokoić wzburzoną opinię międzynarodową i część opinii amerykańskiej. Należała do tych manewrów dyplomacji amerykańskiej, które z jednej strony usiłują stworzyć złudne wrażenie o dążeniu do rokowań, a $\mathrm{z}$ drugiej strony zmierzają do narzucenia rozwiązań, które drogą militarną okazały się nieosiągalne. Skądinąd potrzebny był czas dla przemyślenia sytuacji i poczynienia przygotowań technicznych do nowego szczebla eskalacji. Dotyczyło to szczególnie konieczności przezwyciężenia licznych niedomagań kwatermistrzostwa i infrastruktury w Wietnamie Południowym, które to odcinki wyraźnie nie nadążały za potrzebami eskalacji wojskowej. „Faktycznie - zaznacza James Reston w "The New York Times» z 2 lutego 1966 r. $^{52}$

kambodżańskiej (III CTZ), rejonu Płaskowyżu Centralnego (II CTZ), w delcie Mekongu (IV CTZ) oraz w strefie zdemilitaryzowanej (I CTZ), przede wszystkim w bliskości granic z Laosem i Kambodżą; AIPN, MSW, 01334/634, „Rozwój działań wojennych w Wietnamie. Część IV: siły lądowe", Warszawa, 1968 r., 37; Ahern, CIA and the Generals, 243. Według gen. Westmorelanda terytoria te były kluczowe dla zdobycia w wojnie trwałej inicjatywy operacyjnej i tym samym zapewnienie sobie zwycięstwa; Prados, „American Strategy, 374.

49 W rzeczywistości siły „wolnego świata” zintensyfikowały działania zbrojne, co dostrzegł w swoich opracowaniach wywiad wojskowy PRL. Wykaz operacji odnotowanych przez Zarząd II SG WP informował o 45 operacjach przeciwpartyzanckich przeprowadzonych w $1966 \mathrm{r}$. w sile powyżej jednego batalionu; zob. AIPN, MSW, 01334/633, „Rozwój działań wojennych w Wietnamie. Część III”, Warszawa, 1967 r., 34-38. Od 1 XII 1965 r. do 31 III 1966 r. odnotowywano 27 operacji; ibid., 01334/632, „Rozwój działań wojennych w Wietnamie. Część II”, Warszawa, czerwiec 1967 r., 28-29. Operacje zapoczątkowane w 1966 r. były kontynuowane i finalizowane w latach następnych zob. Lewy, America, 67-78; Wirtz, The Tet Offensive, 42; Pimlott, Wojna, 72-83; Westmoreland, Report on the war in Vietnam (as of 30 June 1968). Section II: report on operations in South Vietnam. January 1964 - June 1968 (Washington D.C.: United States Government Printing Office, 1969), 129, 283; Sacewicz, „Zanim, 371.

50 Bombardowania wstrzymano między 24 XII 1965 r. a 31 I 1966 r. - czyli na 37 dni; Nadolski, Walki powietrzne, 1:221-224; Pentagon Papers, cz. IV.C.7.a, Evolution of the War: The air war in North Vietnam 1965-1968, t. 1, 6-7, 52-59, dostęp styczeń 26, 2020, https://nara-media-001.s3.amazonaws.com/arcmedia/research/pentagon-papers/Pentagon-Papers-Part-IV-C-7-a.pdf; Schandler, America, 67-69; Edward J. Drea, „McNamara, Clifford, and the burdens of Vietnam 1965-1969," w Secretaries of Defense Historical Series, t. 6 (Washington D.C.: Historical Office, Office of the Secretary of Defense, 2011), 63-67. Wznowienie bombardowań odnotowała prasa nie tylko amerykańska; zob. „US bombs North Vietnam again. 4 attacks and 37-day peace pause," The Age, luty 1, 1966 (Melbourne).

51 „Clouds Curtail Bombing," The New York Times, marzec 7, 1966.

52 „Washington: The President Decides," The New York Times, luty 2, 1966. 
- przerwa wypadła w momencie, gdy po stronie alianckiej zaistniał ostry problem dostaw, a tuziny tankowców i okrętów z bronią i innymi ładunkami zostało zamrożonych u wybrzeży Południowego Wietnamu. Sytuacja ta nie tylko została rozładowana podczas przerwy, ale amerykańskie dane oficjalnie wykazują, że Stany Zjednoczone i Południowy Wietnam wwiozły podczas przerwy więcej dostaw niż nieprzyjaciel”.

W lutym 1966 r., a zwłaszcza po konferencji w Honolulu ${ }^{53}$ między prezydentem Johnsonem a marionetkowym Nguyen Cao $\mathrm{Ky}^{54}$, zapowiedziany został nowy - piąty etap eskalacji, który według strategów amerykańskich miał przez same wielkości amerykańskiego zaangażowania doprowadzić do „bezwarunkowego triumfu” amerykańskiego oręża i „totalnego rozwiązania wojskowego" /zob. Bernard Fall ${ }^{55}$ : „Vietnam 1965: das Jahr der verpassten Gelegenheiten”, „Europa-Archiv”, 10 marca 1966 r./. „Wojna na znacznie większą skalę niż w przeszłości uważana jest za nieuniknioną... pisał «US News and World Report» z 7 lutego 1966 r. - Nastąpi systematyczna eskalacja $\mathrm{w}$ wyborze ważnych celów bombardowań". ${ }^{56}$ Kryzys polityczny w Wietnamie Południowym w marcu i kwietniu 1966 w poważnym stopniu pokrzyżował amerykańskie plany wojenne. Niemniej podjęcie od 12 kwietnia bombardowań Demokratycznej Republiki Wietnamu przez strategiczne bombowce B-52 - dotychczas używane tylko w Południowym Wietnamie i zbombardowanie w parę dni później przedmieść Hanoi i Hajfongu były oznakami nowego nasilenia eskalacji. ${ }^{57} \mathrm{U}$ podstaw tego rozwoju wydaje się tkwić rozumowanie podobne do eskalacji 1965 r.; próba zahamowania rozkładu politycznego w Wietnamie Południowym i wykazania, że Waszyngton

53 Na temat postanowień odbywającej się w dniach 6-8 II 1966 r. konferencji w Honolulu; zob. Pentagon Papers, cz. IV.C.9.b, Evolution of the War, US/GVN relations 1963-1967. Part II: July 1965 - December 1967, 9-10, dostęp styczeń 26, 2020, https://nara-media-001. s3.amazonaws.com/arcmedia/research/pentagon-papers/Pentagon-Papers-Part-IV-C-9b.pdf; Ostaszewski, Wietnam, 423.

54 Nguyen Cao Ky (ur. 1930 - zm. 2011) - wietnamski polityk i generał, w 1965 r. po zorganizowaniu zamachu stanu przejął władzę w Wietnamie Południowym, pełniąc do $1967 \mathrm{r}$. funkcję premiera, a następnie do $1971 \mathrm{r}$. sprawował urząd wiceprezydenta Republiki Wietnamu. Po upadku Sajgonu w kwietniu 1975 r. opuścił Indochiny, udając się na emigrację do Stanów Zjednoczonych.

55 Bernard B. Fall (ur. 1926 - zm. 1967) - amerykański korespondent wojenny, jeden z najwybitniejszych publicystów analizujących i opisujących sytuację w Wietnamie, gdzie zginął podczas pracy dziennikarskiej.

56 „No Truce - Bigger War," US News and World Report, luty 7, 1966.

57 W kwietniu doszło do bombardowania strategicznie ważnej przełęczy Mu Giap, nie zaś Hanoi i Hajfongu, szerzej zob. Nadolski, Walki powietrzne, 1:242-243; Schandler, America, 70; Sharp, Report on the war in Vietnam, as of 30 June 1968. Section I: Report on Air and Naval Campaigns against North Vietnam and Pacific Command-wide Support of the War, June 1964 - July 1968 (Washington D.C.: United States Government Printing Office, 1969), 23-24. 
zdecydowany jest kontynuować wojnę mimo rosnącego chaosu na Południu. Istnieje wręcz niebezpieczeństwo - jak wskazał James Reston w „The New York Times" z 15 kwietnia 1965 r. ${ }^{58}$ aby skrajne koła w Pentagonie nie wykorzystywały zamieszania w Sajgonie do narzucenia administracji jeszcze bardziej awanturniczych planów eskalacji wojskowej.

3. Nasileniu eskalacji działań zbrojnych w Wietnamie odpowiada skokowy wzrost nakładów finansowych i ilości zaangażowanych $\mathrm{w}$ tej wojnie sił wojskowych USA. Wydatki amerykańskie na cele interwencji w Wietnamie wzrosły od $200 \mathrm{mln}$ dolarów w 1961 r. do $400 \mathrm{mln}$ w 1963 r., $500 \mathrm{mln}$ w 1964 r. i 15,8 mld dolarów przeznaczonych na wojnę w roku budżetowym 1965/66/„Times”, 5 lutego 1966 r./..$^{59}$ Ogólne koszty cywilne i wojskowe wojny w Wietnamie w roku 1966 oceniane są w Waszyngtonie na sumę 25 mld dolarów / „Le Monde”, 9 kwietnia 1966 r. $/{ }^{60}$ Uwzględniając deprecjację dolara od czasów wojny koreańskiej, wojna w Wietnamie pochłania już obecnie w skali rocznej sumy równe wydatkom Stanów Zjednoczonych na wojnę koreańską na przestrzeni trzech lat. ${ }^{61}$ Odpowiednio wzrosła też liczba wojsk amerykańskich zaangażowanych bezpośrednio w wojnie. Korpus ekspedycyjny w Południowym Wietnamie, liczący w końcu 1964 r. 23300 oficerów osiągnął w końcu 1965 r. blisko 200 tys. oficerów i żołnierzy, a w kwietniu 1966 r. 250 tys. oficerów i żołnierzy. ${ }^{62}$ Dochodzi do tego tysięczna załoga

58 „Washington: The Lull in Saigon; The New Candor The Planning Committees More Formal Meetings Hopes and Fears," The New York Times, kwiecień 15, 1966.

59 „Danger of General War in South-East Asia,” The Times, luty 5, 1966.

60 „Les manifestations redoublent de violence à Saigon Le «directoire» militaire confère avec le général Westmoreland LES ÉTATS-UNIS FACE AU VIETNAM I. - Le poids de la guerre," Le Monde, kwiecień 9, 1966.

${ }_{61}$ W 1965 r. amerykańskie wydatki na wojnę - według opracowań wywiadu wojskowego PRL - wynosiły 0,1 mld dolarów, zaś w 1966 r. 5,8 mld dolarów; zob. AIPN, MSW, 01791/24 t. 2, „Rozwój działań wojennych na Półwyspie Indochińskim w latach 1968-1974 (załączniki)", Warszawa, 1974 r., 13. Według innego z opracowań Zarządu II SG WP koszt jednego dnia działań bojowych w 1965 r. wynosił 1 mln dolarów, w końcu 1966 r., wraz z intensyfikacją aktywności operacyjnej, koszt jednego dnia działań bojowych wzrósł do 3,7 mln dolarów; ibid., 01521/718 t. 3, „Zbiór wiadomości o działaniach wojennych w Wietnamie”, z. 6, Warszawa, 1967 r., 21. Kolejne opracowanie wywiadowcze z 1968 r. informowało, że od sierpnia 1964 r. do 1967 r. władze amerykańskie na prowadzenie wojny w Wietnamie przeznaczyły 47,2 mld dolarów, a średnie miesięczne koszty działań bojowych przekroczyły 2 mld dolarów; ibid., 01334/634, „Rozwój działań wojennych w Wietnamie. Część IV: siły lądowe", Warszawa, 1968 r., 13, 47. Dane z opracowań Departamentu Armii potwierdzają powyższe, wysokie koszty obecności militarnej USA na Półwyspie Indochińskim. W 1966 r. na działania na terenie Azji Południowo-Wschodniej przewidywano w budżecie - 12,3 mld dolarów; Leonard B. Taylor, Vietnam Studies: Financial Management of the Vietnam Conflict 1962-1972 (Washington D.C.: Departament of the Army, 1974), 20-23.

62 Zob. przypis nr 26. 
7 floty działającej na wybrzeżu Wietnamu ${ }^{63}, 15$ tys. żołnierzy amerykańskich w bazach lotniczych w Syjamie ${ }^{64}$ i 7 tys. w bazie na wyspie Guam, obsługującej bombowce B-52 ${ }^{65}$ Razem w wojnie wietnamskiej zaangażowanych już było w kwietniu 1966 r. bezpośrednio ponad 330 tys. oficerów i żołnierzy amerykańskich wszystkich rodzajów broni. ${ }^{66}$ Do końca 1966 r. zapowiedziany jest dalszy wzrost tych sił do okrągłej liczby pół miliona żołnierzy. ${ }^{67}$ Tonaż bomb zrzuconych na Wietnam Północny i Południowy w pierwszym roku bombardowań do lutego 1966 r. wyniósł 250 tys. ton, a według wypowiedzi McNamary ma przekroczyć w 1966 r. liczbę 600 tys. ton, czyli tyle ile Amerykanie zrzucili podczas II wojny światowej w rejonie całego Pacyfiku lub podczas całej wojny koreańskiej. ${ }^{68}$ Według zeznań

63 Ze składu 7 Floty, która grupowała ponad 600 jednostek w tym ok. 200 bojowych z 12 lotniskowcami (zob. AIPN, MSW, 01521/718 t. 3, „Zbiór wiadomości o działaniach wojennych w Wietnamie", z. 6, Warszawa, 1967 r., 15), na potrzeby działań zbrojnych w Azji Południowo-Wschodniej według danych na sierpień $1967 \mathrm{r}$. wydzielono: 3 lotniskowce uderzeniowe, 2 lotniskowce desantowe, 37 okrętów desantowych, 2 krążowniki, 33 niszczyciele i fregaty, 3 okręty podwodne, 6 trałowców i 3 okręty wsparcia ogniowego. Łącznie było to ponad 35 tys. marynarzy. Wsparcia udzielało im lotnictwo US Navy; ibid., 01791/24 t. 2, „Rozwój działań wojennych na Półwyspie Indochińskim w latach 1968-1974 (załączniki)”, Warszawa, 1974 r., 30-31. W następnych latach stopień zaangażowania jednostek 7 Floty w działania na wodach wokół Półwyspu Indochińskiego ulegał zmianie; zob. ibid., 0665/133, „Doświadczenia amerykańskich sił morskich w wojnie wietnamskiej (Zagadnienia użycia floty)", Warszawa, 1971 r., 8; Zarząd II Sztabu Generalnego Wojska Polskiego, 2602/7976, Załącznik nr 1 pt. „Notatka informacyjna - skład bojowy i liczbowy sił zbrojnych USA i innych państw kapitalistycznych w południowo-wschodniej Azji na dzień 10.01.1968 r.", Hanoi, 20 II 1968 r., 24-25. Według oceny Zarządu II zadania marynarki wojennej Stanów Zjednoczonych podczas działań zbrojnych w Wietnamie, w tym i wydzielonego komponentu z 7 Floty, polegać miały: „1. wykonywaniu uderzeń za pomocą lotnictwa pokładowego i artylerii okrętowej na obiekty DRW, celem niszczenia potencjału militarnego ekonomicznego tego kraju. 2. kontrola żeglugi kabotażowej wzdłuż całego wybrzeża Wietnamu i żeglugi śródlądowej w Wietnamie Południowym, w celu przerwania dostaw zaopatrzenia i przerzutu sił NFW [Narodowego Frontu Wyzwolenia]. 3) wsparcie ogniowe piechoty morskiej i sil lądowych w Wietnamie południowym”; AIPN, MSW, 01334/639, „Rozwój działań wojennych w Wietnamie. Część IX: technika bojowa sił morskich”, Warszawa, 1969 r., 9. Do realizacji tych działań przekierowane zostały także okręty ze składu floty rezerwowej.

${ }^{64}$ Obecnie Tajlandia. Nazwa Syjam funkcjonowała do 1948 r. jako oficjalna nazwa państwa Tajów.

65 Zob. też Sacewicz, „Zanim,” 383.

${ }_{66}$ Pod koniec 1966 r. siły amerykańskie w Wietnamie przekroczyły 385 tys. żołnierzy; Ostaszewski, Wietnam, 426; Pimlott, Wojna, 178.

67 W grudniu 1968 r. liczba Amerykanów w Wietnamie wynosiła 536100 żołnierzy; zob. Pimlott, Wojna, 178.

68 Wzrost tonażu bomb zrzuconych na cele komunistyczne w Południowym oraz Północnym Wietnamie był konsekwencją eskalacji wojny powietrznej. W 1965 r. przeprowadzono 25 tys. lotów bojowych, w 1966 r. 79 tys., w 1967 r. ponad 108 tys. zob. Ostaszewski, Wietnam, 424; James T. Correl, The Air Force in the Vietnam War (Arlington: Aerospace 
McNamary przed komisją senacką sił zbrojnych w styczniu 1966 r. same koszty amunicji zużywanej przez Amerykanów w Wietnamie wynoszą 100 mln dolarów miesięcznie, a koszt bomb lotniczych około $110 \mathrm{mln}$ dolarów miesięcznie /„Le Monde”, 9 kwietnia 1966 r./. ${ }^{69} \mathrm{O}$ wysokości nakładów amerykańskich świadczą oceny kosztów zabicia 1 partyzanta. Wahają się one od 375 tys. do pół miliona dolarów /„Newsweek”, 14 luty 1966 r./. ${ }^{70}$

4. W miarę nasilenia eskalacji i barbarzyństwa wojny rosną również straty agresorów amerykańskich. Najdotkliwsze są straty w ludziach. Według oficjalnych raportów amerykańskich straty wojsk USA wynoszą od 500 do blisko 1000 zabitych i rannych tygodniowo. Liczba zabitych żołnierzy amerykańskich w okresie od początku 1966 r. do 9 kwietnia br. była wyższa niż w ciągu całego 1965 r. Przeciętna zabitych - według danych oficjalnych - osiągnęła w I kwartale 1966 r. 100 żołnierzy amerykańskich tygodniowo. Liczby te wydają się znacznie zaniżone. Dane ze źródeł powstańczych obliczają straty wojsk amerykańskich w I kwartale 1966 r. na 25 tys. oficerów i żołnierzy w tym 9 pełnych batalionów amerykańskich. ${ }^{71}$ Wysokość strat,

Education Foundation, 2004), 16. Przy czym dane te obejmują jedynie działania USAF. Dopiero przy uwzględnieniu nalotów dokonywanych także przez lotnictwo US Navy, USMC oraz Sił Powietrznych Wietnamu Południowego (VNAF) otrzymujemy pełny obraz wojny powietrznej w Indochinach. W sumie na cele w DRW oraz w Republice Wietnamu w $1966 \mathrm{r}$. przeprowadzono 291967 lotów bojowych, zaś w 1967 r. 359353; Correll, The Air Force, 14. W 1965 r. USAF na same cele w DRW zrzucily 63 tys. ton bomb, w 1966 r. 136 tys. ton bomb, w 1967 r. 226 tys. ton bomb; Theyer, War, 82. Warto też zauważyć, że USAF dokonały podczas wojny wietnamskiej 5226701 lotów bojowych, podczas gdy w latach II wojny światowej 2362 800, a koreańskiej 710886 lotów; Correl, The Air Force, 26.

69 „Les manifestations redoublent.”

70 „The War in Vietnam. The Bombers Go North," Newsweek, luty 14, 1966. O wysokich kosztach prowadzenia. walk w Wietnamie świadczy m.in. sprawa nalotu bombowego wykonanego przez 30 bombowców strategicznych B-52 w ramach operacji o kryptonimie „Rock Kick II” w nocy z 11 na 12 IV 1966 r. na przełęcz Mu Giap. W jego wyniku zniszczono drogę, którą siły komunistyczne naprawiły w 24 godziny, zaś nalot kosztował amerykańskich podatników ok. 21 mln dolarów; Nadolski, Walki powietrzne, 1:242.

71 Pod koniec 1965 r. liczba zabitych żołnierzy amerykańskich szacowana była na 1369 przy wielkości kontyngentu 181 tys.; Ostaszewski, Wietnam, 414; The war in Vietnam. Prepared by the Staff of the Senate Republican Policy Committee (Washington D.C.: The Glad Day, 1967), 60. Warto podkreślić, że starty Amerykanów w Wietnamie od 1961 r. do końca 1965 r. wyniosły: 1864 zabitych, 7337 rannych i 18 zaginionych w akcji. W 1966 r. w walce zginęło 5008 amerykańskich żołnierzy, zaś kolejnych 1045 zmarło bez udziału nieprzyjaciela. Tym samym śmierć poniosło 6053 amerykańskich żołnierzy. Rannych było 29992, zaś 61 zaginęło w akcji. Kontyngent USA w grudniu 1966 r. wynosił 385300 żołnierzy; zob. „Summary of Vietnam Casualty Statistics,” dostęp marzec 17, 2020, https://www.ktroop.com/HonorRoll/ casualty.pdf. Nowe obliczenia dokonane przez National Archives trochę odbiegają od tych przedstawionych przez stowarzyszenie weteranów wojny wietnamskiej i tym samym dają nieco odmienne spojrzenie na skalę strat wojsk amerykańskich. Według ustaleń z kwietnia 2008 r. w 1965 r. w Wietnamie zginęło 1928 Amerykanów, zaś w 1966 r. 6350; zob. „DCAS 
zwłaszcza personelu wykwalifikowanego - lotników, oficerów, specjalistów - znajduje najlepsze odbicie w fakcie wyczerpania rezerw całej armii amerykańskiej. /zob. Hanson W. Baldwin w „The New York Times”, 9-10 kwietnia 1966 r./ ${ }^{72}$ i konieczności przerzucenia do Wietnamu 30 tys. wyszkolonego personelu amerykańskiego z NRF [Niemieckiej Republiki Federalnej].

Wysoka jest również stopa strat lotnictwa amerykańskiego. Według danych Demokratycznej Republiki Wietnamu do maja 1966 r. lotnictwo amerykańskie pod niebem Północnego Wietnamu straciło 1000 samolotów. $^{73}$ Dane powstańcze z Południowego Wietnamu podają liczby jeszcze wyższe. Tylko w I kwartale 1966 r. Amerykanie, według komunikatów powstańczych, stracili 890 samolotów i helikopterów /zestrzelonych, zniszczonych lub uszkodzonych $/ .^{74}$ Straty te zadawane są głównie podczas śmiałych raj-

Vietnam Conflict Extract file record counts by Incident or Death Date (year)," dostęp styczeń 31, 2020, https://www.archives.gov/research/military/vietnam-war/casualty-statistics\#date. Te wyższe liczby i tak nie potwierdzają informacji zawartych w materiale lektorskim o stratach bezpowrotnych w I kwartale 1966 r. na poziomie 25 tys. osób. Co prawda informacja o utracie przez USA 9 batalionów piechoty - mając na uwadze, że ówczesny stan batalionu piechoty złożonego z 4 kompanii wynosił 656 żołnierzy daje liczbę 5904, a więc zbliżoną do oficjalnych danych amerykańskich o stratach poniesionych do końca grudnia 1966 r., może wydawać się wiarygodny, niemniej jednak należy pamiętać, że materiał KC PZPR powstał w czerwcu 1966 r., a więc w okresie, kiedy starty bezpowrotne wojsk amerykańskich w Wietnamie nie osiągnęły tej liczby. Ponadto dane prezentowane przez Wydział Propagandy i Agitacji KC PZPR były zawyżone także w stosunku do ustaleń wywiadu wojskowego PRL. W opracowaniu Zarządu II z 1968 r. informowano, że w latach 1961-1964 Amerykanie stracili w Wietnamie Południowym 267 żołnierzy, w 1965 r. - 1369, a w 1966 r. 5008 żołnierzy. W latach 1961-1964 rannych zostało 1531; AIPN, MSW, 01334/634, „Rozwój działań wojennych w Wietnamie. Cz. IV: siły lądowe”, Warszawa, 1968 r., 46.

72 Zob. „U.S. War Construction in Southeast Asia to Hit Peak in Summer," The New York Times, kwiecień 10, 1966.

73 Zupełnie inne dane podaje strona amerykańska. Według raportu operacyjnego Sił Powietrznych Stanów Zjednoczonych z 30 XI 1973 r. od początków lutego 1962 r. do końca października $1973 \mathrm{r}$. w wyniku działań bojowych w powietrzu, a także ataków na amerykańskie lotniska utracono 2255 maszyn różnego typu. Z czego w latach 1962-1966 - 457 maszyn, a w 1967 r. 401 maszyn. Należy jeszcze podkreślić, że w latach 1964-1973 lotnictwo wojskowe armii południowowietnamskiej utraciło ponad 1 tys. samolotów i śmigłowców; Correl, The Air Force, 25-26.

74 Należy zwrócić uwagę, że wielkości odbiegające od amerykańskich danych podawały opracowania wywiadu wojskowego PRL. Według tychże w 1962 r. zniszczono 200 maszyn, w 1963 r. - 695, w 1964 r. - 1027, w 1965 r. - 1337 i w 1966 r. - 2130. Raporty te podawały, że do 1967 r. straty amerykańskiego lotnictwa były dwukrotnie wyższe niż podczas całej II wojny światowej; zob. AIPN, MSW, 01521/718 t. 3, „Zbiór wiadomości o działaniach wojennych w Wietnamie”, z. 6, Warszawa, 1967 r., 20-21. Oczywiście było to kłamstwem. Porównawcze zestawienia całościowego wysiłku lotnictwa bojowego USA podczas II wojny światowej, wojny koreańskiej oraz wojny w Wietnamie wskazują co prawda dwukrotnie większą liczbę lotów bojowych podczas walk nad Wietnamem w stosunku do okresu II wojny światowej, jednak straty były proporcjonalnie niższe. W II wojnie światowej Amerykanie, 
dów powstańczych na amerykańskie bazy wojskowe. Na przykład w ataku na lotnisko w Sajgonie w dniu 13 kwietnia br., według danych amerykańskich partyzanci zniszczyli 33 samoloty i helikoptery /„New York Herald Tribune", 14 kwietnia 1966 r./ $/^{75}$ Amerykanie oczywiście nie przyznają się do tak wysokich strat ogólnych. Przemawiając w styczniu br. przed senacką komisją sił zbrojnych McNamara podał, że do końca 1965 r. Stany Zjednoczone straciły w Wietnamie 413 samolotów i helikopterów / „Le Monde”, 22 stycznia 1966 r./ Dodał przy tym, że na wyrównanie strat w samolotach konieczna jest suma 1,8 mld dolarów /„New York Herald Tribune”, 21 stycznia 1966 r. $/^{76} \mathrm{O}$ rzeczywistych rozmiarach strat świadczy uwaga Hanson[a] W. Baldwina ${ }^{77}$, że zdolność produkcyjna przemysłu amerykańskiego ,jest zaledwie wystarczająca dla uzupełnienia strat lotnictwa bojowego i operacyjnego" /,The New York Times”, 7 kwietnia 1966 r./ Jakkolwiek straty materialne nie są tego rzędu, aby wyczerpały olbrzymie zasoby gospodarcze Stanów Zjednoczonych, niemniej w powiązaniu ze stratami ludzkimi zaczynają poważnie obciążać saldo wojenne administracji amerykańskiej.

5. Krwawy impas wojskowy wojny wietnamskiej - zwłaszcza w powiązaniu $\mathrm{z}$ aspektami politycznymi $\mathrm{w}$ Południowym Wietnamie i na arenie międzynarodowej - może mieć określony wpływ na zmiękczenie stanowiska stron i utorowanie drogi do rokowań. W kołach wojskowych wywołuje on jednak reakcję innego rodzaju tendencję do zmiany układu sił i przeważenia szali środkami militarnymi. Po obu stronach rysuje się orientacja na niszczenie żywych sił nieprzyjaciela, jako najbardziej skutecznej metody działania. Trudna do realizacji przez wojska amerykańskie - ze względu na specyfikę wojny partyzanckiej i szerokie zaplecze ludzkich sił powstańczych - orientacja ta wydaje się towarzyszom wietnamskim ważnym ogniwem strategii, która ma zadecydować o kolejach wojny. Wszystko wskazuje na to, że w tym kierunku zmierzają przygotowania do następnej fazy wojny wyzwoleńczej. Można więc oczekiwać w rozpoczynającej się od maja porze deszczowej i na jesieni 1966 r. nasilenia walk w Południowym Wietnamie, których głównym celem ze strony sił powstańczych będzie znaczne zwiększenie strat ludzkich agresora amerykańskiego. Najbliższym zadaniem wydaje się osiągnięcie skali koreańskiej w niszczeniu żywych sił wojsk amerykańskich, czyli kilkakrotne pomnożenie aktualnej stopy strat.

wykonując 2362800 lotów stracili 22948 maszyn, co dawało średnio utratę 9,7 maszyny na 1 tys. lotów, podczas gdy w Wietnamie wykonując 5226701 lotów utracili 2257 maszyn, co stanowiło stratę 0,4 maszyny na 1 tys. lotów bojowych; zob. Correl, The Air Force, 25.

75 Mowa o ataku Viet Congu na lotnisko Tan Son Nhut niedaleko Sajgonu.

76 Na temat planowania budżetowego na rok 1966 zob. Drea, McNamara, 101 i n.

77 Hanson W. Baldwin (ur. 1903 - zm. 1991) - amerykański dziennikarz-publicysta wojenny, redaktor działu wojskowego New York Times'a, laureat nagrody Pulitzera. 
Zakłada się określoną współzależność między stopą strat wojsk amerykańskich a dojrzewaniem warunków, w których możliwe będzie uregulowanie konfliktu. $[\ldots]^{78}$

Źródło: AAN, KC PZPR Wydział Propagandy i Agitacji, 1354/237/VIII-827, „Uwagi o dynamice konfliktu wietnamskiego /Materiał lektorski/", Warszawa, czerwiec 1966 r., 2327, mps.

\section{Bibliografia}

\section{Archiwalia}

Archiwum Akt Nowych

Komitet Centralny Polskiej Zjednoczonej Partii Robotniczej

Archiwum Instytutu Pamięci Narodowej w Warszawie

Ministerstwo Spraw Wewnętrznych w Warszawie

Zarząd II Sztabu Generalnego Wojska Polskiego

\section{Wydawnictwa źródłowe}

Allen, John K. Jr., John Carver i Tom Elmore. Red. Estimative Products on Vietnam 1948-1975. Pittsburgh: Government Printing Office, 2005.

„DCAS Vietnam Conflict Extract file record counts by Incident or Death Date (year)." Dostęp styczeń 31, 2020, https://www.archives.gov/research/military/vietnam-war/casualty-statistics\#date.

„FM 3-18. Special Forces Operations, Headquarters Department of the Army." Washington D.C.: Create Space Independent Publishing Platform, 2014.

Grant Sharp, Ulysses. S. Report on the war in Vietnam, as of 30 June 1968. Section I: Report on air and naval campaigns against North Vietnam and Pacific Command-wide support of the war, June 1964 - July 1968. Washington D.C.: United States Government Printing Office, 1969.

Gravel, Mike, red. The Pentagon Papers. Gravel Edition. T. 1-4. Boston: Beacon Pess, 1972. Dostęp luty 21, 2020. https://www.mtholyoke.edu/acad/intrel/pentagon/doc1. htm.

Office of the Historian. „Telegram from the Department State to the Embassy in Vietnam, Washington, December 14, 1961.” Dostęp styczeń 27, 2020. https://history. state.gov/historicaldocuments/frus1961-63v01.

Pentagon Papers. Cz. IV.A.4. Evolution of the War: U.S. Training of the Vietnamese National Army 1954-1959. Dostęp styczeń 26, 2020, https://nara-media-001.s3. amazonaws.com/arcmedia/research/pentagon-papers/Pentagon-Papers-Part-IV-A-4.pdf.

78 Pominięto dalszą część materiału lektorskiego poświęconą kwestiom niemilitarnym, tj.: realiom politycznym sceny wietnamskiej, odbiorowi konfliktu przez społeczeństwa państw zachodnich, reakcji społeczeństwa amerykańskiego, postawie państw obozu socjalistycznego oraz potencjalnym możliwościom uregulowania konfliktu. 
Pentagon Papers. Cz. IV.B.2. Evolution of the War. Counterinsurgency: The strategic Hamlet Program 1961-1963. Dostęp styczeń 26, 2020, https://nara-media-001. s3.amazonaws.com/arcmedia/research/pentagon-papers/Pentagon-Papers-Part-IV-B-2.pdf.

Pentagon Papers. Cz. B.IV.4. Evolution of the War. Counterinsurgency: Phased withdrawal of U.S. Forces 1962-1964. Dostęp styczeń 26, 2020, https://nara-media-001. s3.amazonaws.com/arcmedia/research/pentagon-papers/Pentagon-Papers-Part-IV-B-4.pdf.

Pentagon Papers. Cz. IV.B.5. Evolution of the War. Counterinsurgency. The Kennedy Commitments 1961-1963: The Overthrow of Ngo Dinh Diem. May-November, 1963. Dostęp styczeń 26, 2020, https://nara-media-001.s3.amazonaws.com/arcmedia/ research/pentagon-papers/Pentagon-Papers-Part-IV.-B-5.pdf.

Pentagon Papers. Cz. IV.C.2.c. Evolution of the War. Direct Action. The Johnson Commitments 1964-1968. Military pressures against North Vietnam, November-December 1964, part III: Military pressures against North Vietnam: November 1964 - January 1965. Dostęp styczeń 26, 2020, https://nara-media-001.s3.amazonaws.com/ arcmedia/research/pentagon-papers/Pentagon-Papers-Part-IV-C-2c.pdf.

Pentagon Papers. Cz. IV.C.7. Evolution of the War: The air war in North Vietnam 1965-1968l, volume 1. Dostęp styczeń 26, 2020, https://nara-media-001.s3. amazonaws.com/arcmedia/research/pentagon-papers/Pentagon-Papers-Part-IV -C-7.pdf.

Pentagon Papers. Cz. IV.C.9 b. Evolution of the War, US/GVN relations 1963-1967. Part II: July 1965 - December 1967. Dostęp styczeń 26, 2020, https://naramedia-001.s3.amazonaws.com/arcmedia/research/pentagon-papers/PentagonPapers-Part-IV-C-9-b.pdf.

Pentagon Papers. Cz. V.B.4. The Kennedy Administration. Book 2. Dostęp styczeń 26, 2020, https://nara-media-001.s3.amazonaws.com/arcmedia/research/pentagon-papers/Pentagon-Papers-Part-V-B-4.pdf.

„Summary of Vietnam Casualty Statistics.” Dostęp marzec 17, 2020. https://www.ktroop. com/HonorRoll/casualty.pdf.

The Text of the Contoversial Republican White Paper. The war in Vietnam. Prepared by the Staff of the Senate Republican Policy Committee. Washington D.C.: Public Affairs Press, 1967.

The war in Vietnam. Prepared by the Staff of the Senate Republican Policy Committee. Washington D.C.: The Glad Day, 1967.

Westmoreland, William C. Report on the war in Vietnam (as of 30 June 1968). Section II: report on operations in South Vietnam. January 1964 - June 1968. Washington D.C.: United States Government Printing Office, 1969.

\section{Opracowania}

Adamczyk, Marcin i Szuflet Oskar. Indochiny w amerykańskiej polityce powstrzymywania do 1963 roku. Poznań: Wydawnictwo Wierzejewski, 2017.

Ahern, Thomas L. Jr. CIA and the Generals cover Support to military Government in South Vietnam. B.m.w.: Center for the Study of Intelligence, [1998].

Ahern, Thomas L. Jr. CIA and Rural Pacification in South Vietnam. B.m.w.: Center for the Study of Intelligence, [2001]. 
Anderson, David L. The Columbia Guide to the Vietnam War. New York: Columbia University Press, 2002.

Benken, Przemysław. Ap Bac 1963 - Binh Gia 1964. Dwie bitwy, które zmieniły bieg wojny w Wietnamie. Zabrze - Tarnowskie Góry: Inforteditions, 2018.

Clark, Jeffrey J. Advice and Support: The Final Years 1965-1973. Washington: Center of Military History United States Army, 1988.

Correl, James T. The Air Force in the Vietnam War. Arlington: Aerospace Education Foundation, 2004.

Cosmas, Graham A. History of the Joint Chiefs of Staff. The Joint Chiefs of Staff and the War in Vietnam, 1960-1968. Part II. Washington D.C.: Office of Joint History, Office of the Chairman of the Joint Chiefs of Staff, 2012.

Dudman, Richard. „Military Policy in Vietnam.” Current History 50, nr 294 (1966): 91-97.

Fulbright, J. William. The Arrogance of Power. New York: Random House Publishing Group, 1967.

Gruszka, Katarzyna. „Rolling Thunder - pierwsza amerykańska ofensywa powietrzna w Wietnamie." W Studia nad wojnami w Indochinach. T. 1. Red. Przemysław Benken, 122-135. Oświęcim: Napoleon V, 2013.

Jian, Chen. „China's Involvement in the Vietnam War, 1964-69." The China Quarterly, nr 142 (1995): 356-387.

Kolko, Gabriel. Anatomy of a War. Vietnam, the United States and the Modern Historical Experience. New York: Pantheon, 1986.

Laurie, Clayton D. i Vaart Andres, Studies in Intelligence. Journal of the American Intelligence Professional: CIA and the Wars in Southeast Asia 1947-1975, (sierpień 2016).

Lewy, Guenter. America in Vietnam. Oxford - New York: Oxford University Press, 1978.

Maj, Ewa. „Zaangażowanie Stanów Zjednoczonych w konflikt wietnamski w świetle polskiej propagandy prasowej (1964-1968)." W Zimowa Szkoła Historii Najnowszej 2014. Referaty. Red. Marek Hańderek i Łukasz Kamiński, 108-118. Warszawa: Wyd. Instytutu Pamięci Narodowej, 2015.

Nadolski, Łukasz M. Walki powietrzne nad Wietnamem Północnym w latach 19651968 na tle operacji Rolling Thunder. T. 1. Lata 1965-1967. Toruń: Wyd. Nauk. Uniwersytetu Mikołaja Kopernika, 2016.

Nadolski, Łukasz M. Walki powietrzne nad Wietnamem Północnym w latach 19651968 na tle operacji Rolling Thunder. T. 2. Lata 1967-1968. Bydgoszcz: Muzeum Wojsk Lądowych, 2018.

Ostaszewski, Piotr. Wietnam. Najdłuższy konflikt powojennego świata 1945-1975. Warszawa: „DiG”, 2000.

Pawłuszko, Tomasz, „Teoria bezpieczeństwa a teoria pokoju.” W Bezpieczeństwo międzynarodowe. Polska-Europa-Świat. Księga Jubileuszowa dedykowana Profesorowi Ryszardowi Ziębie z okazji czterdziestolecia pracy naukowej. Red. Justyna Zając, Agata Włodkowska-Bagan i Marcin Kaczmarski, 59-72. Warszawa: Wydział Dziennikarstwa i Nauk Politycznych Uniwersytetu Warszawskiego, 2015.

Pimlott, John. Wojna w Wietnamie. Tłum. Małgorzata Malczyk. Warszawa: „Morex”, 1993. 
Polmar, Norman i Edward J. Marolda. The U.S. Navy and the Vietnam War. Naval Air War. The Rolling Thunder Campaign. Washington D.C.: Naval History \& Heritage Command, Naval Historical Foundation, 2015.

Prados, John. „American Strategy in the Vietnam war.” W The Columbia History of the Vietnam War. Red. David L. Anderson, 247-261. New York: Columbia University Press, 2001.

Sacewicz, Karol. „Zanim była Ofensywa Tet. Sytuacja operacyjna wojsk amerykańskich i sojuszniczych w Wietnamie Południowym w 1967 r. i jej wpływ na walki w dolinie Dak To w świetle materiałów Zarządu II Sztabu Generalnego Wojska Polskiego. Krytyka źródła.” Pamięć i Sprawiedliwość, nr 35 (2019): 366-409.

Schandler, Hebert Y. America in Vietnam: The War That Couldn't Be Won. Lanham: Rowman \& Littlefield Publishers, 2009.

Schulismon, Jack. History of the Joint Chiefs of Staff. The Joint Chiefs of Staff and the War in Vietnam 1960-1968. Part 1. Washington D.C.: Office of Joint History, Office of the Chairman of the Joint Chiefs of Staff, 2011.

Stech, Bogdan. Wojna powietrzna nad Wietnamem. Warszawa: „Lampart”, 1995.

Taylor, Leonard B. Vietnam studies: Financial Management of the Vietnam Conflict 1962-1972. Washington D.C.: Departament od the Army, 1974.

Thayer, Thomas C. War without Fronts. The American Experience in Vietnam. Annapolis: Naval Institute Press, 2016.

Tym, Juliusz S. „Konflikty lokalne podczas zimnej wojny jako wyraz konfrontacji zbrojnej mocarstw bez wypowiedzenia wojny." Studia Martima 29, (2016): 236-246.

Westmoreland, William C. A Soldier Reports. New York: Doubleday, 1976.

Wirtz, James J. The Tet Offensive. Intelligence Failure in War. Ithaca: Cornell University Press, 1994.

Xiaobing, Li. A History of the Modern Chinese Army. Lexington, Ky: The University Press of Kentucky, 2007.

\section{Prasa}

„Clouds Curtail Bombing." The New York Times, marzec 7, 1966.

„Danger of Geeral War in South-East Asia," The Times, luty 5, 1966.

„Les manifestations redoublent de violence à Saigon Le «directoire» militaire confère avec le général Westmoreland LES ÉTATS-UNIS FACE AU VIETNAM I. - Le poids de la guerre." Le Monde, kwiecień 9, 1966.

„No Truce - Bigger War.” US News and World Report, luty 7, 1966.

„Text of Mansfield Panel's Conclusions.” The New York Times, styczeń 8, 1966.

„The untold story of Vietnam war." US News and World Report, styczeń 24, 1966.

„The War in Vietnam. The Bombers Go North.” Newsweek, luty 14, 1966.

„U.S. War Construction in Southeast Asia to Hit Peak in Summer." The New York Times, kwiecień 10, 1966.

„US bombs North Vietnam again. 4 attacks and 37-day peace pause.” The Age, luty 1, 1966 (Melbourne).

„Washington: The Lull in Saigon; The New Candor The Planning Committees More Formal Meetings Hopes and Fears." The New York Times, kwiecień 15, 1966.

„Washington: The President Decides.” The New York Times, luty 2, 1966. 


\section{STRESZCZENIE}

\section{Karol Sacewicz, Sytuacja militarna uczestników wojny wietnamskiej w świetle fragmentów materiału lektorskiego Wydziału Propagandy i Agitacji KC PZPR pt. Uwagi o dynamice konfliktu wietnamskiego (czerwiec 1966)}

Wojna w Wietnamie, znana również jako II konflikt indochiński, była wydarzeniem, które w znaczący sposób determinowało sytuację zimnowojenną w latach sześćdziesiątych i siedemdziesiątych XX w. Kwestia ta była również obserwowana i analizowana nad Wisłą. Oczywiście największą uwagę obecność militarna armii Stanów Zjednoczonych w Południowym Wietnamie budziła w czynnikach wojskowych PRL, niemniej jednak również była to problematyka znajdująca się w zasięgu zainteresowania czynników partyjnych. W 1966 r. Wydział Propagandy i Agitacji KC PZPR przygotował i rozesłał po strukturach wojewódzkich partii wykład lektorski pt. Uwagi o dynamice konfliktu wietnamskiego.

Niniejszy tekst jest krytyczną edycją fragmentu dokumentu dotyczącą aspektów militarnych toczącej się wówczas wojny. Stanowi próbę ukazania nie tylko sposobu postrzegania wojny wietnamskiej przez propagandę PRL, ale także odsłania komunistyczną manipulację i proces tworzenia własnego - ahistorycznego obrazu wietnamskich zmagań.

Słowa kluczowe: wojna w Wietnamie, propaganda, zimna wojna, Wydział Propagandy i Agitacji Komitetu Centralnego PZPR

\section{SUMMARY}

Karol Sacewicz, The military Situation of the Vietnam War Participants in Light of lecture Material produced by the Central Committee of the Polish United Workers' Party's Department of Propaganda and Agitation entitled Notes on the Dynamics of the Vietnam Conflict (June 1966)

The Vietnam War, also known as the Second Indochina War, was an event that significantly impacted the ongoing Cold War during the 1960s and 1970s. The conflict was also observed and analyzed in the Polish People's Republic. Of course, the country's military institutions paid the greatest attention to the US military presence in South Vietnam, but party elements also took an interest in the situation. In 1966, the Central Committee of the Polish United Workers' Party (via the Department of Propaganda and Agitation) prepared and disseminated lecture material concerning the dynamics of the Vietnamese conflict through its provincial party structures.

This text is a critical edition of a fragment of a document concerning the military aspects of the war that was taking place at that time. It is not only an attempt to present a Polish People's propaganda way of seeing the Vietnam War, but it also 
reveals the existence of communist manipulation and the process behind the creation of an ahistorical image of the Vietnamese struggle.

Keywords: Vietnam War, propaganda, Cold War, Department of Propaganda and Agitation of the Central Committee of the Polish United Workers' Party

\begin{abstract}
АННОТАЦИЯ
Кароль Сацев ич, Военное положение участников вьетнамской войны в свете фрагментов лекций Отдела пропаганды и агитации ЦК Польской объединенной рабочей партии под названием Замечания к динамике въетнамского конфликта (июнь 1966 г.)
\end{abstract}

Война во Вьетнаме, также известная как Вторая Индокитайская война, была событием, которое в значительной степени определило ситуацию холодной войны в 1960-х и 1970-х г. Этот вопрос также изучался и анализировался на Висле. Конечно, наибольший интерес к военному присутствию США в Южном Вьетнаме вызвали военные факторы Польской Народной Республики, но и партийные факторы также играли здесь свою роль. В 1966 г. отдел пропаганды и агитации ЦК Польской объединенной рабочей партии подготовил и разослал по воеводским структурам лекцию под названием „Замечания к динамике вьетнамского конфликта”.

Этот текст представляет собой критическую редакцию фрагмента документа, касающегося милитарных аспектов длящейся в то время войны. Это попытка не только показать восприятие войны во Вьетнаме пропагандой Польской Народной Республики, но еще и раскрыть коммунистические манипуляции и процесс создания собственного - неисторического - образа вьетнамской борьбы.

Ключевые слова: война во Вьетнаме, пропаганда, холодная война, отдел пропаганды и агитации ЦК Польской объединенной рабочей партии 